\title{
Ionic Mechanism of the Outward Current Induced by Intracellular Injection of Inositol Trisphosphate into Aplysia Neurons
}

\author{
Masashi Sawada, Mitsuyuki Ichinose, and Takashi Maeno \\ Department of Physiology, Shimane Medical University, Izumo, Japan
}

Inositol 1,4,5-trisphosphate (InsP $\mathrm{P}_{3}$ ) has been proposed to be the intracellular second messenger in the mobilization of $\mathrm{Ca}^{2+}$ from intracellular stores in a variety of cell types. The ionic mechanism of the effect of intracellularly injected Ins $\mathrm{P}_{3}$ on the membrane of identified neurons (R9-R12) of Aplysia kurodai was investigated with conventional voltage-clamp, pressure-injection, and ion-substitution techniques. Brief pressure injection of Ins $\mathrm{P}_{3}$ into a neuron voltage-clamped at $-40 \mathrm{mV}$ reproducibly induced an outward current (10-60 sec in duration, 20-60 nA in amplitude) associated with a conductance increase. The current was increased by depolarization and decreased by hyperpolarization up to $-\mathbf{8 0}$ $\mathrm{mV}$, where it disappeared. Extracellular application of tetraethylammonium (TEA; $5 \mathrm{~mm}$ ) blocked the Ins $_{3}$-induced outward current, and the current was not affected by the presence of bath-applied 4-aminopyridine (4-AP; $5 \mathrm{~mm}$ ). The Ins $\mathrm{P}_{3}$-induced outward current recorded at a holding potential of $-\mathbf{4 0} \mathrm{mV}$ increased in amplitude in low-K+ solutions and decreased in amplitude in high-K $\mathrm{K}^{+}$solutions. Alteration of $\left[\mathrm{Cl}^{-}\right]_{0}$, as well as perfusion with $\mathrm{Ca}^{2+}$ free plus 2 mM EGTA solution, did not affect the outward current. The Ins $P_{3}$-induced outward current was found to disappear when the neuron was injected with the $\mathrm{Ca}^{2+}$ chelator EGTA. The outward current evoked by repeated Ins $\mathrm{P}_{3}$ injection at low doses exhibited summation and facilitation and, at high doses, was shown to desensitize. The calmodulin inhibitor $\mathbf{N}$-(6-aminohexyl)-5-chloro-1-naphthalene sulfonamide (W-7; 20-50 $\mu \mathrm{M})$, inhibited both the Ins $\mathrm{P}_{3}$-induced and the $\mathrm{Ca}^{2+}$-activated outward currents. An intracellular pressure injection of $\mathrm{Ca}^{2+}$ ions into the same identified neuron was shown to produce an outward current associated with a $\mathrm{K}^{+}$conductance increase similar to the InsP $\mathrm{P}_{3}$-induced current, and the current was blocked by bath-applied TEA ( $5 \mathrm{mM})$. These results suggest that brief pressure injection of $\operatorname{lns}_{3}$ into certain identified neurons of Aplysia induces a 4-AP-resistant, TEA-sensitive $\mathrm{K}^{+}$current activated by increased intracellular free $\mathrm{Ca}^{2+}$ concentration, and this increase might be the result of the mobilization of $\mathrm{Ca}^{2+}$ from intracellular stores by $\operatorname{lns} \mathbf{P}_{3}$.

Received July 25, 1986; revised Nov. 19, 1986; accepted Nov. 25, 1986

This work was supported in part by Grants-in-Aid for Scientific Research from the Ministry of Education, Science, and Culture of Japan (61570068). We wish to thank Dr. J. E. Blankenship for helpful discussions and correction of the English manuscript. We also thank Dr. K. Imai for his help in the preparation of Ins $P_{3}$, Ms. Y. Takeda for typing the manuscript, and Mr. S. Saito for a constant supply of Aplysia kurodai.

Correspondence should be addressed to Dr. Masashi Sawada at the above address.

Copyright (C) 1987 Society for Neuroscience $0270-6474 / 87 / 051470-14 \$ 02.00 / 0$
It has been proposed that hydrolysis of phosphatidylinositol4,5-bisphosphate (PI- $\left.\mathrm{P}_{2}\right)$ is involved in the control of a variety of physiological processes (Michell, 1975; Berridge, 1984). Recent studies have implicated inositol 1,4,5-trisphosphate ( $\left.\operatorname{Ins}_{3}\right)$ as an intracellular messenger in the cascade mediating hormone-, neurotransmitter-, and light-induced physiological responses (Berridge, 1983; Streb et al., 1983; Fein et al., 1984; Joseph et al., 1984; Oron et al., 1985; Waloga and Anderson, 1985; Hashimoto et al., 1986).

Berridge and his collaborators (1983) have demonstrated that the first measurable reaction following cell membrane receptor activation is a rapid hydrolysis of PI- $\mathrm{P}_{2}$, and that the product of this reaction, Ins $P_{3}$, could cause a release of nonmitochondrial $\mathrm{Ca}^{2+}$. These findings have been verified in other systems (Agranoff et al., 1983; Poggioli et al., 1983; Putney et al., 1983). It has recently been demonstrated that Limulus ventral photoreceptors possess the pathways for the synthesis of $\mathrm{PI}-\mathrm{P}_{2}$ and for its subsequent light-induced hydrolysis to produce $\operatorname{Ins}_{3}$ (Brown et al., 1984). In addition, the intracellular injection of $\mathrm{InsP}_{3}$ into the Limulus photoreceptor (Brown et al., 1984; Fein et al., 1984) and into salamander rod (Waloga and Anderson, 1985) has been shown to mimic several aspects of the light-induced response. Furthermore, Oron and his collaborators (1985) have demonstrated that the intracellular injection of Ins $\mathrm{P}_{3}$ into the Xenopus oocyte mimics a muscarinic depolarizing chloride current. These results are consistent with the possibility that $\operatorname{Ins}_{3}$ might play a role as an intracellular messenger mediating an increase in the conductance of the neuronal membrane activated by neurotransmitters. In molluscan neurons in which $\mathrm{Ca}^{2+}$-activated $\mathrm{K}^{+}$ conductance has been studied extensively, it has been shown that a small increase in intracellular $\mathrm{Ca}^{2+}$ can produce a sizable increase in $\mathrm{K}^{+}$conductance (Hermann and Gorman, 1979; Hermann and Hartung, 1982).

In the present study, we investigated the ionic mechanism of an Ins $\mathrm{P}_{3}$-induced outward current using micropressure injection of InsP $\mathrm{P}_{3}$ into identified neurons (R9-R12) of Aplysia kurodai and compared the current with a $\mathrm{Ca}^{2+}$-activated $\mathrm{K}^{+}$current recorded from the same neuron. Our results indicate that brief micropressure injection of InsP $_{3}$ into these identified neurons of Aplysia induces an outward current associated with an increase in $\mathrm{K}^{+}$conductance and showing the same ionic and pharmacological properties as currents evoked by $\mathrm{Ca}^{2+}$ injection into the same neuron.

\section{Materials and Methods}

Identified R9-R 12 (nomenclature of Frazier et al., 1967) neurons in the abdominal ganglion of $A p l y s i a$ and approximately 80 animals, weighing from 100 to $300 \mathrm{gm}$, were used in this study. Isolated, desheathed abdominal ganglia were pinned, ventral surface upward, to a Sylgard 
A
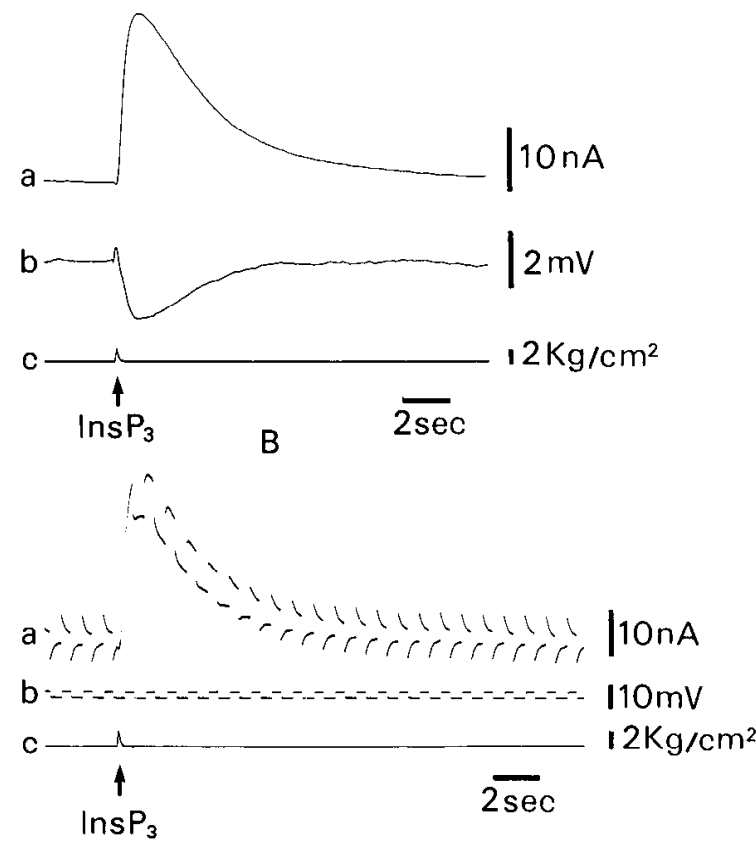

Figure 1. Micropressure injection of Ins $\mathrm{P}_{3}$ into identified neuron $\mathrm{R} 12$. Ins $\mathrm{P}_{3}$ was prepared from human erythrocyte ghosts and injected by a single constant pressure pulse $\left(60 \mathrm{msec}\right.$ in duration, $2 \mathrm{~kg} / \mathrm{cm}^{2}$ in intensity; calculated final concentration of $\left.\operatorname{Ins}_{3}, 0.4 \mu \mathrm{M}\right)$. InsP $\mathrm{P}_{3}$-induced outward current $(A, a)$, Ins $\mathrm{P}_{3}$-induced hyperpolarizing response $(A, b)$, and Ins $\mathrm{P}_{3}$-induced outward current associated with an increase in the membrane conductance $(B), A, a$ : Neuron $\mathrm{R} 12$ in voltage-clamp at a holding potential of $-40 \mathrm{mV} ; b$ : neuron $\mathrm{R} 12$ in current-clamp with membrane potential of $-40 \mathrm{mV}$; $c$ : pressure monitor for intracellular injection of Ins: $P_{3} . B, a$ : Membrane current; $b$ : holding potential $(-40 \mathrm{mV}) ; c$ : pressure monitor. Ins $P_{3}$ was injected by a constant pressure pulse $(70 \mathrm{msec}$ duration; $2 \mathrm{~kg} / \mathrm{cm}^{2}$ intensity). Constant hyperpolarizing command pulses $(2 \mathrm{mV})$ with a duration of $500 \mathrm{msec}$ were injected every $1 \mathrm{sec}$ and the current required for these pulses was recorded for measurement of membrane conductance $(B)$. Note that the Ins $_{3}$-induced outward current was typically associated with an apparent increase in the membrane conductance.
(Dow-Corning) floor in a $0.3 \mathrm{ml}$ perfusion chamber containing artificial Aplysia Ringer's: $587 \mathrm{~mm} \mathrm{Na}^{+}, 12 \mathrm{~mm} \mathrm{~K}+, 671 \mathrm{~mm} \mathrm{Cl}^{-}, 14 \mathrm{~mm} \mathrm{Ca}^{2+}$, and $52 \mathrm{mM} \mathrm{Mg}^{2+}$ (a slight modification of the Aplysia Ringer's originally made by Sato et al., 1968). The $\mathrm{pH}$ was adjusted to 7.8 with Tris(hydroxymethyl)-aminomethane and $\mathrm{HCl}$. The rate of perfusion was 4 $\mathrm{ml} / \mathrm{min}$. The $\mathrm{K}^{+}$-deficient solutions were produced by mixing appropriate amounts of $\mathrm{K}^{+}$-free Aplysia Ringer's with normal Aplysia Ringer's. When the Ringer's solution required a low $\mathrm{Cl}^{-}$ion concentration, the $\mathrm{Cl}^{-}$ion was replaced by an acetate ion. Zero $\mathrm{Ca}^{2+}-2 \mathrm{~mm}$ EGTA seawater was made by substituting $14 \mathrm{mM} \mathrm{MgCl}_{2}$ for $14 \mathrm{mM} \mathrm{CaCl}_{2}$ and adding 2 mM EGTA to artificial Aplysia Ringer's.

An identified neuron was impaled with a double- or triple-barreled microelectrode. One barrel, filled with $4 \mathrm{M} \mathrm{K}$ acetate, was connected to a preamplifier in order to record the membrane potential; the other barrel, filled with either InsP $\mathrm{P}_{3}(0.8 \mathrm{~mm})$ or $\mathrm{CaCl}_{2}(10 \mathrm{~mm})$, was used for pressure injection. A second microelectrode, filled with $4 \mathrm{M} \mathrm{K}$ acetate, was inserted into the neuron for voltage-clamp. The neuron was voltageclamped conventionally with a 2 -microelectrode system (using the voltage-clamp amplifiers CEZ-1100 and MEZ-7101; Nihon Kohden) and held at resting membrane potential. $\mathrm{An} \mathrm{Ag}-\mathrm{AgCl}$ electrode with an agarseawater bridge was immersed in the bath and served as the indifferent electrode and virtual ground. The membrane potential and the current were monitored by a dual-beam oscilloscope (VC-9A; Nihon Kohden) and a 4-channel pen recorder (Recti Horiz-8K; Sanei) with selected signal filtering. In order to evaluate the change in membrane conductance, the resting membrane was hyperpolarized every $1 \mathrm{sec}$ by a voltage pulse of $2 \mathrm{mV}$ with a duration of $500 \mathrm{msec}$, and the current required for this constant hyperpolarizing pulse was recorded before and during the responses to $\operatorname{Ins}_{3}$ or $\mathrm{Ca}^{2+}$, injected intracellularly into the identified neuron.

Several substances were injected intracellularly, with pressure pulses of $0.8-2.0 \mathrm{~kg} / \mathrm{cm}^{2}$, for $10-900 \mathrm{msec}$ (using a PPM-2 pneumatic pump; (Medical System Corp.). Either double-barreled or triple-barreled electrodes were used for intracellular injection of $\operatorname{InsP}_{3}(0.8 \mathrm{mM})$, myoinositol ( $1 \mathrm{~mm})$, and $\mathrm{CaCl}_{2}(10 \mathrm{~mm})$. The second barrel was always filled with $4 \mathrm{M} \mathrm{K}$ acetate and used to record membrane potential. Electrodes for pressure injection were filled with $20 \mathrm{mg} / \mathrm{ml}$ Procion red and one of the above substances dissolved in distilled water $(\mathrm{pH}=7.4)$. Procion red was used to allow visual verification that solutions were being injected into the neurons. Control injections of either Procion red or myoinositol had no obvious adverse effects on membrane current and conductance of the neurons (Fig. $2, A, C$ ).

In several experiments, the volume of solution pressure-injected was quantified using a modification of the method of McCaman et al. (1977). Calibration of a particular microelectrode was accomplished by measurement of the diameter of the spherical droplet formed under varying
A
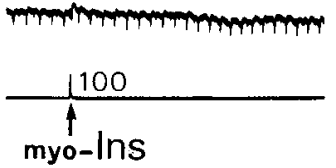

B
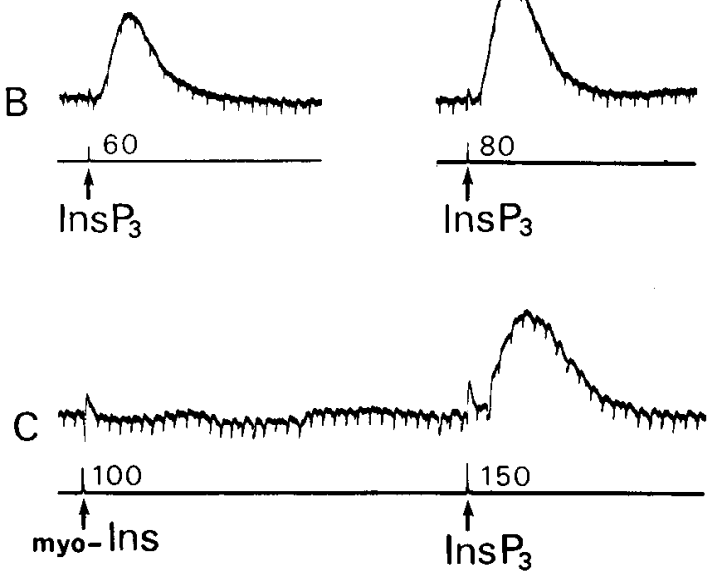
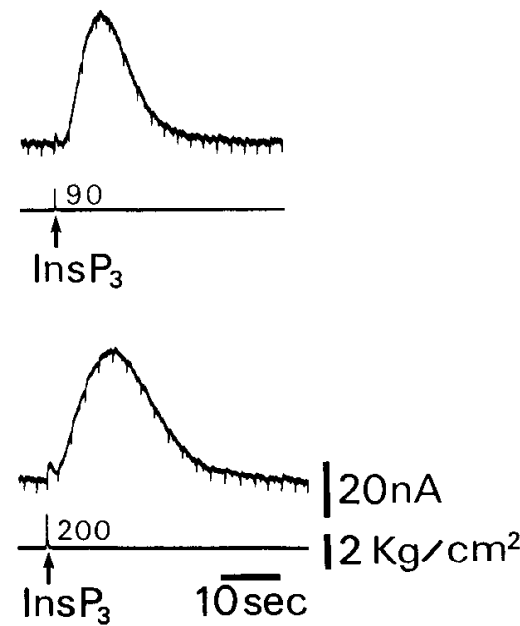

Figure 2. Intracellular injection of myo-inositol (myo-ins, $A, C$ ), Procion red $(P . R ., A)$, and $I n s P_{3}(B, C)$ into neuron R12 from a triple:barreled microelectrode. myo-Inositol was injected by a constant pressure pulse $(100 \mathrm{msec}, 2$ $\mathrm{kg} / \mathrm{cm}^{2}$ ) using 1 barrel filled with $1 \mathrm{~mm}$ myo-inositol. Procion red was injected by a constant pressure pulse ( $100 \mathrm{msec}$, $2 \mathrm{~kg} / \mathrm{cm}^{2}$ ) using the second barrel filled with $20 \mathrm{mg} / \mathrm{ml}$ Procion red solution. InsP $P_{3}$ was injected by pressure pulses (60-200 msec, $\left.2 \mathrm{~kg} / \mathrm{cm}^{2}\right)$ using the third barrel filled with $0.8 \mathrm{~mm}$ InsP $\mathrm{P}_{3}$ (Amersham). Holding potential of neuron R12 was $-35 \mathrm{mV}$. Numbers represent the duration of the pressure pulse $(\mathrm{msec})$ in this and subsequent figures. Note that neither myo-inositol nor Procion red induced any changes in membrane current, but InsP $P_{3}$ injected into the same neuron R12 induced the outward current in a dose-dependent manner. 
A

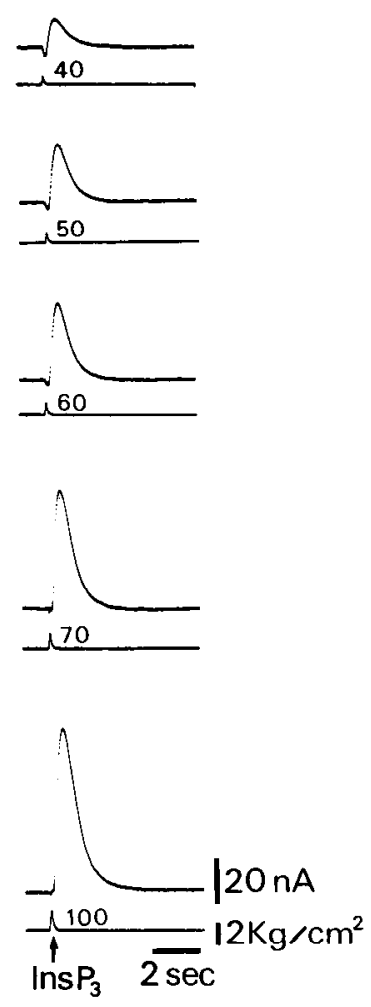

B

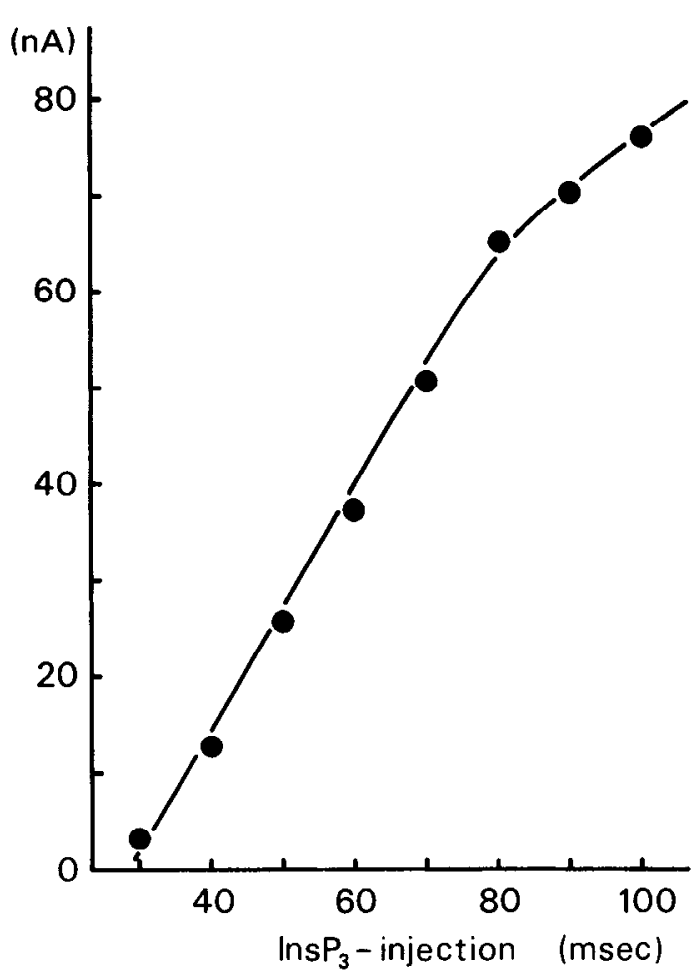

C
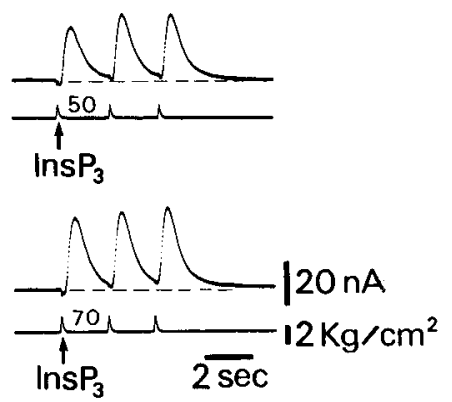

Figure 3. Ins $\mathrm{P}_{3}$ outward currents induced by Ins $\mathrm{P}_{3}$ injections of different durations at a constant pressure intensity $\left(2 \mathrm{~kg} / \mathrm{cm}^{2}\right)$ into neuron $\mathrm{R} 12$. One of a triple-barreled microelectrode was filled with $0.8 \mathrm{~mm} \mathrm{Ins} \mathrm{P}_{3}$. Pressure-injected $\mathrm{Ins}_{3}$ in this and subsequent experiments (except in Fig. $5 A$ ) was obtained from Amersham. $A$, Membrane current responses to pressure-injected Ins $\mathrm{P}_{3}$ of different durations. $B$, Relationship between the duration of pressure for the InsP $\mathrm{P}_{3}$ injection and the peak of the InsP $\mathrm{P}_{3}$-induced outward current. $C$, Effect of repetitive injection of InsP ${ }_{3}$ into neuron $\mathrm{R} 12$. Ins $\mathrm{P}_{3}$ was injected by constant pressure pulses $\left(50 \mathrm{msec}, 2 \mathrm{~kg} / \mathrm{cm}^{2}\right.$, top; $70 \mathrm{msec}, 2 \mathrm{~kg} / \mathrm{cm}^{2}$, bottom) every $2 \mathrm{sec}$ into neuron R12. Holding potential, $-\mathbf{3 5} \mathrm{mV}$.

pressure- and pulse-duration combinations. Droplets were formed in the neuron or were ejected into oil (Toray AH 200-100) and the diameter was measured with an ocular micrometer (Hara et al., 1985). Injection quantities were in the range of $0.01-0.3 \%$ of the cell volume and were delivered at a pressure-pulse duration of 10-900 msec under constant pressure $\left(2 \mathrm{~kg} / \mathrm{cm}^{2}\right)$. A pressure pulse of $250 \mathrm{msec}$ duration usually produced an injection on the order of $0.05 \%$ of the ccll volumc. This was normally sufficient to induce responses.

In an initial series of experiments, InsP $\mathrm{P}_{3}$ was prepared by incubating human erythrocyte ghosts with $\mathrm{CaCl}_{2}$, followed by a Dowex formate column separation, and then desalted by elution from a Dowex chloride column with $1 \mathrm{M} \mathrm{LiCl}$, and the $\mathrm{LiCl}$ removed with ethanol (Downes et al., 1982). In most experiments, D- $m y o$-inositol 1,4,5-trisphosphate (InsP $\mathrm{P}_{3}$ isolated from bovine brain) (Amersham) was pressure-injected into the identified neurons. Mircropressure injection of InsP $P_{3}$, obtained either from human erythrocyte ghosts or from bovine brain, was shown to induce a similar outward current in the identified neurons.

Drugs applied extracellularly were added to the artificial Aplysia Ringer's. The following drugs were used: myo-inositol (Sigma); InsP (potassium salt; Amersham); 4-aminopyridine (4-AP; Nakarai); tetraethylammonium chloride (TEA; Sigma); EGTA (Sigma); $N$-(6-aminohexyl)-5-chloro-1-naphthalene sulfonamide (W-7; Sigma); ACh (Nakarai); and Procion red (Inolex).

All experiments were performed at room temperature $\left(19-22^{\circ} \mathrm{C}\right)$.

\section{Results}

\section{Identification of neuron}

The identified neurons (R9-R12) are usually in the ventral right rostral quarter of the abdominal ganglion of Aplysia kurodai. These neurons are homologous to R9-R 12 of Aplysia californica (Frazier et al., 1967) in appearance (white), location, and physiological properties (regular firing and hyperpolarizing response to ACh) (Koester and Kandel, 1977). The majority of the data presented here were obtained using identified neuron R12.

\section{Ins $P_{3}$-induced outward current}

Micropressure-injected Ins $\mathrm{P}_{3}$ caused a marked hyperpolarization in the nonclamped neuron R12. Clamping the neuron at its resting potential level $(-40 \mathrm{mV})$ and reinjecting $\operatorname{Ins}_{3}$ with the same dose resulted in the development of a transmembrane outward current with the same time course as the membrane hyperpolarization in the nonclamped condition (Fig. 1A). Although both the time course and the delay from the beginning of the injection to the onset of the $\mathrm{InsP}_{3}$-induced outward current recorded at -40 to $-45 \mathrm{mV}$ were found to be neuron- and ganglion-dependent, they remained the same for a given neuron in a given ganglion. The change in input conductance produced by Ins $\mathrm{P}_{3}$ injection was directly measured by applying constantvoltage hyperpolarizing pulses while clamping the neuron at resting membrane potential (Fig. $1 B$ ). The InsP $\mathrm{P}_{3}$-induced outward current reached a maximum amplitude $(20-60 \mathrm{nA})$ within $1 \mathrm{sec}$ and lasted at least 10-60 sec. It was typically associated with an apparent increase in membrane conductance, as illustrated in Figure $1 B$ and subsequent figures. At the peak of the $\mathrm{InsP}_{3}$-induced outward current there was a $400 \%$ increase in input-membrane conductance (Fig. $1 B$ ). The outward current response to injected Ins $\mathrm{P}_{3}$ was observed in over 86 of the identified neurons studied (54 R12, 18 R11, 6 R10, and 8 R9). With a single injection (pressure pulse duration, $60 \mathrm{msec}$; pressure 
A
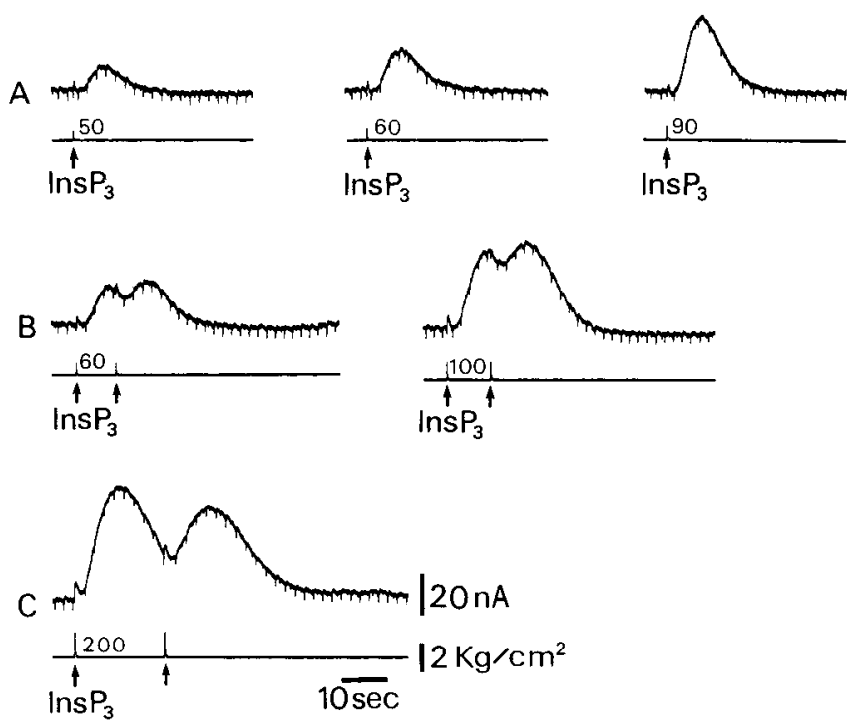

Figure 4. Intracellular injection of $\operatorname{Ins}_{3}$ at different pulse durations into neuron $\mathrm{R} 12$. Holding potential, $-35 \mathrm{mV} . A$, Ins $\mathrm{P}_{3}$ was injected by 3 different pressure pulses $\left(50,60\right.$, and $\left.90 \mathrm{msec} ; 2 \mathrm{~kg} / \mathrm{cm}^{2}\right)$. $B$, InsP was injected by a short pressure pulse $\left(60 \mathrm{msec}, 2 \mathrm{~kg} / \mathrm{cm}^{2}\right)($ left $)$ and by two $100 \mathrm{msec}$ pulses at short intervals (right). $C$, InsP $\mathrm{P}_{3}$ was injected by two $200 \mathrm{msec}$ pressure pulses $\left(2 \mathrm{~kg} / \mathrm{cm}^{2}\right)$. Note that, in $B$, repeated injection of $\mathrm{InsP}_{3}$ at low amounts caused a summation, but in $C$ caused a desensitization at higher amounts.

intensity, $2 \mathrm{~kg} / \mathrm{cm}^{2}$ ), the calculated concentration of $\operatorname{InsP}_{3}$ in neuron R12 (300 $\mu \mathrm{m}$ in diameter; cell volume, $14.2 \mathrm{nl})$ was 0.4 $\mu \mathrm{M}$ when the injection clectrode was filled with $0.8 \mathrm{~mm} \mathrm{InsP}_{3}$ (see Methods in Hara et al., 1985).

In order to check the specificity of the inhibitory effect of Ins $\mathrm{P}_{3}$, a variety of control solutions was also pressure-injected into the neurons and found to be without a noticeable effect on the membrane current. As a rule, injection of either myo-inositol or Procion red, using the same injection pressure pulse as with the $\mathrm{InsP}_{3}$ injection (the electrode used was filled with $1 \mathrm{~mm}$ $m y o$-inositol or $20 \mathrm{mg} / \mathrm{ml}$ Procion red solution), did not induce any observable current response (Fig. $2 A, C$ ).

Both the amplitude and delay (the time measured between the pressure artifact and the onset of response) of the $\mathrm{InsP}_{3}$ induced outward current obtained by injection of $\operatorname{InsP}_{3}$ at a medium-sized dose were dependent on the position of the injection electrode. A larger amplitude and shorter delay of the Ins $\mathrm{P}_{3}$-induced outward current were recorded when the injection electrode was positioned nearer the cell membrane than the central soma. The Ins $\mathrm{P}_{3}$-induced outward current at a holding potential of $-35 \mathrm{mV}$ increased in a dose-dependent manner, i.e., the current amplitude increased with an increase in the duration of the pressure pulse (Fig. 3, $A, B$ ). The peak of the outward current responses rose linearly with the duration of the pulse for $\mathrm{InsP}_{3}$ injection. The straight line fitted to the experimental points has a slope of $57 \mathrm{nA}$ per $50 \mathrm{msec}$-injected $\mathrm{InsP}_{3}$ load, using a constant pressure intensity of $2 \mathrm{~kg} / \mathrm{cm}^{2}$, but does not pass through the origin, which indicates that a certain minimum amount of Ins $\mathrm{P}_{3}$ has to be injected to activate the outward current. With increasing duration of the injection pressure pulse, the delay from the beginning of injection to the onset of response is shortened, the rise of the outward current faster, and the time for the outward current to peak is prolonged.

Repetitive injection of $\operatorname{InsP}_{3}$ pulses of brief duration at short

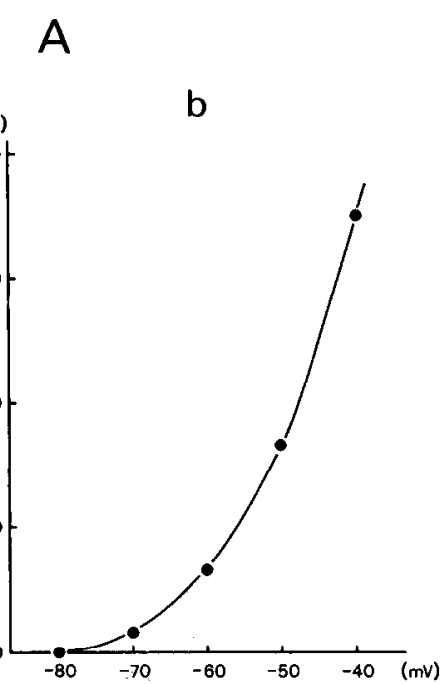

B
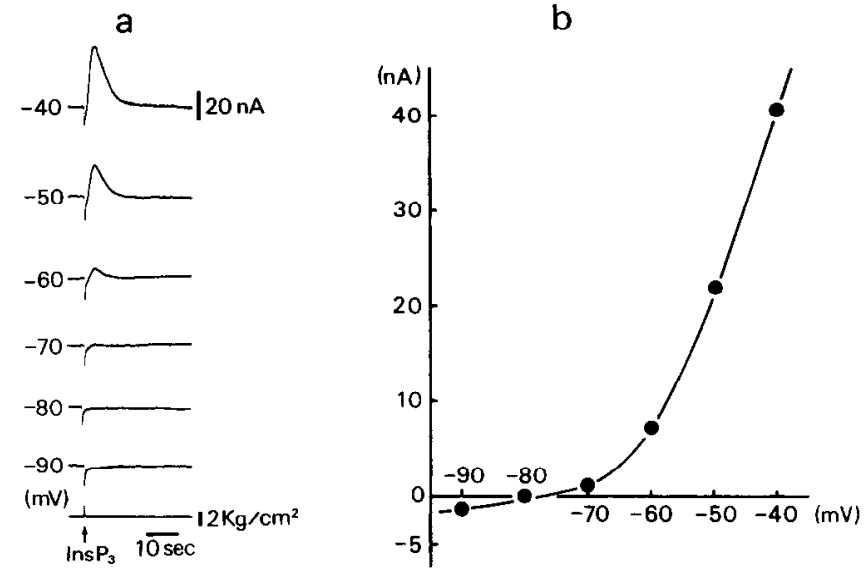

Figure 5. InsP $\mathrm{P}_{3}$-induced outward currents $(A, a)$ at different holding potentials and voltage sensitivity of these currents $(A, b)$ recorded from the same neuron used in Figure 1 (R12). Pressure-injected Ins $\mathrm{P}_{3}$ in this experiment was prepared from human erythrocyte ghosts. InsP $\mathrm{P}_{3}$ was injected by a constant pressure pulse $\left(100 \mathrm{msec}, 2 \mathrm{~kg} / \mathrm{cm}^{2}\right)$. Note that the Ins $\mathrm{P}_{3}$-induced outward current decreased at holding potentials more hyperpolarized than $-40 \mathrm{mV}$ and disappeared near the predicted equilibrium potential for $\mathrm{K}^{+}$ions $(-80 \mathrm{mV})$. Ins $\mathrm{P}_{3}$-induced outward currents $(B, a)$ at different holding potentials, and voltage sensitivity of these currents $(B, b)$ recorded from neuron $\mathrm{R} 12$ in a different preparation. Pressure-injected InsP $\mathrm{P}_{3}$ in this experiment was obtained from Amersham. InsP $P_{3}$ was injected by a single constant pressure pulse $(100 \mathrm{msec}$, $2 \mathrm{~kg} / \mathrm{cm}^{2}$ ). Note that the Ins $P_{3}$-induced outward current reversed at hyperpolarized holding potentials more negative than $-80 \mathrm{mV}$, and the reversal potential of the Ins $\mathrm{P}_{3}$-induced outward current was $-78.5 \mathrm{mV}$.

intervals ( $2 \mathrm{sec}$ ) leads to an increased amplitude of the Ins $\mathrm{P}_{3}$ induced outward current. With an interval of $2 \mathrm{sec}$, the second Ins $\mathrm{P}_{3}$-induced outward current was increased, although the 2 responses did not overlap (Fig. $3 C$, top). The descriptive term facilitation may be used for this phenomenon. When the InsP injections followed more closely in time (less than $2 \mathrm{sec}$ ), the InsP $\mathrm{P}_{3}$-induced outward current overlapped and summation also occurred (Fig. $3 C$, bottom; Fig. $4 B$ ). On the other hand, repetitive injections at short intervals of higher amounts of $\mathrm{InsP}_{3}$ into neuron R12 led to a decreased amplitude of the second Ins $\mathrm{P}_{3}$-induced outward current, indicating that desensitization had occurred (Fig. 4C). 
Figure 6. Lack of effect of $\mathrm{Cl}^{-}{ }_{0}$-deficient seawater $(A)$ and effects of high $\mathrm{K}^{+}{ }_{0}$ seawater $(B, C)$ and low- $\mathrm{K}^{+}{ }_{0}$ seawater $(C)$ on the $\operatorname{InsP}_{3}$-induced outward current recorded from neuron $\mathrm{R} 12$. Holding potentials were $-45 \mathrm{mV}$ in $A$ and $B,-35 \mathrm{mV}$ in $C$. InsP ${ }_{3}$ was injected by a single constant pressure pulse ( $80 \mathrm{msec}, 2 \mathrm{~kg} / \mathrm{cm}^{2}$ in $A$ and $B$; $200 \mathrm{msec}, 2 \mathrm{~kg} / \mathrm{cm}^{2}$ in $C$ ). Normal seawater NSW represents normal Aplysia Ringer's in this and subsequent figures. A, Left: control; center: nine minutes after $\mathrm{R} 12$ was exposed to $\mathrm{Cl}^{-}{ }_{0}$-deficient $\left(0.5 \times\right.$ normal $\left.\mathrm{Cl}^{-}\right)$seawater; right: nine minutes after washout. $B$, Left: control; center: five minutes after $\mathrm{R} 12$ was exposed to high- $\mathrm{K}^{+}{ }_{0}\left(2 \times\right.$ normal $\left.\mathrm{K}^{+}\right)$seawater; right: nine minutes after washout. C, Left: control; center (left side): six minutes after R12 was exposed to high- $\mathrm{K}^{+}{ }_{0}\left(2 \times\right.$ normal $\left.\mathrm{K}^{+}\right)$seawater; center (right side): nine minutes after washout; right: six minutes after R12 was exposed to $\mathrm{K}^{+}{ }_{0}$-deficient $(0.2 \times$ normal $\mathrm{K}^{+}$) seawater.
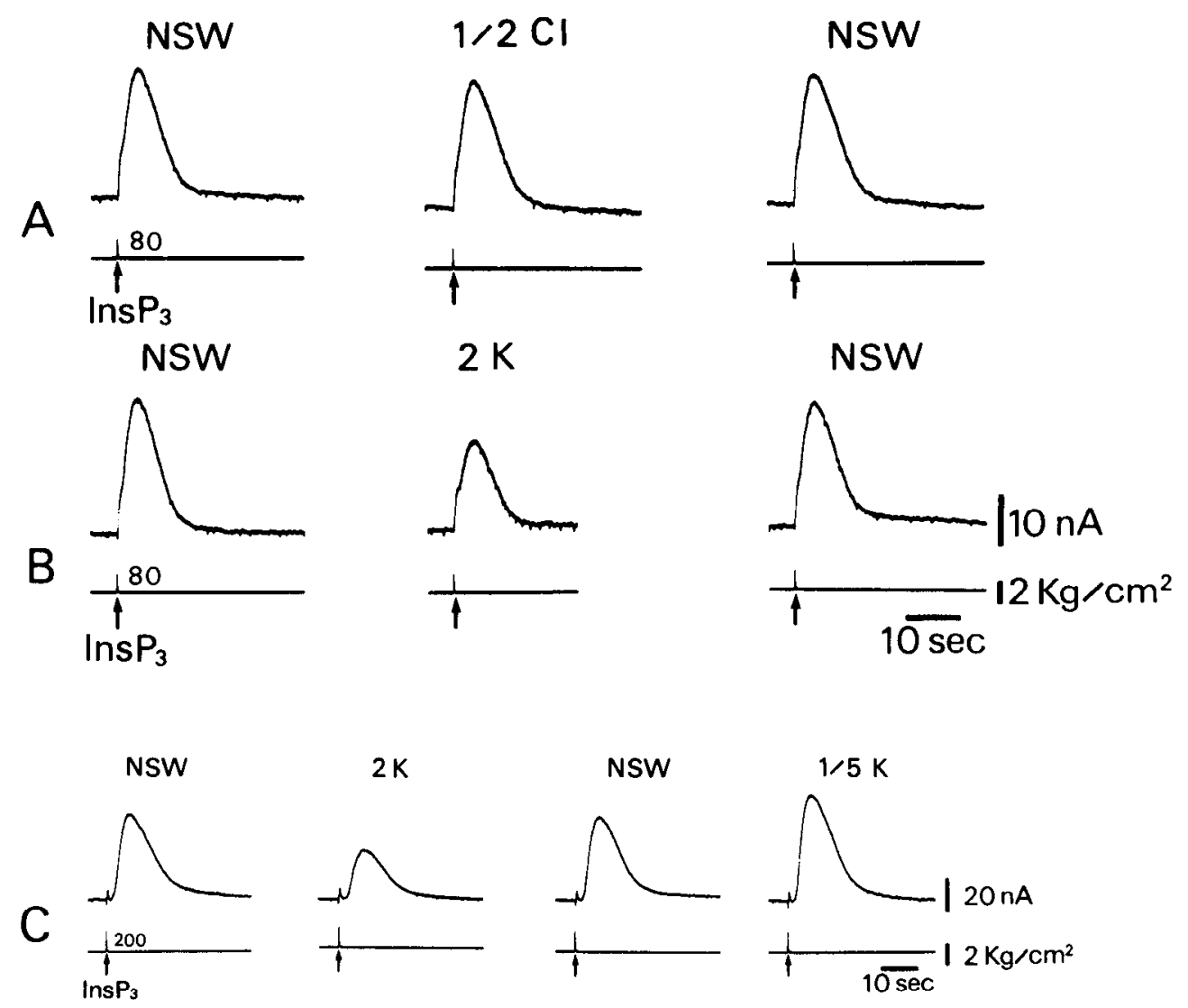

an increase in $\mathrm{K}^{+}$conductance. The effects of increasing and decreasing the extracellular potassium concentration $\left(\mathrm{K}^{+}{ }_{0}\right)$ on the $\mathrm{InsP}_{3}$-induced outward current, elicited by a single constant pressure injection of InsP $P_{3}$ into neuron R12, are illustrated in Figure $6, B, C$. If the InsP ${ }_{3}$-induced outward current were due simply to an increase in $\mathrm{K}^{+}$conductance, one would expect that the current recorded at a holding potential of $-45 \mathrm{mV}$ would be increased during exposure to a $\mathrm{K}^{+}{ }_{0}$-deficient solution and decreased in a high- $\mathrm{K}^{+}{ }_{v}$ solution. Increasing $\mathrm{K}^{+}{ }_{0}$ from 12 to 24 $\mathrm{mM}$ caused a marked decrease in the $\mathrm{InsP}_{3}$-induced outward current $(58.2 \pm 7.5 \%$ of control, mean $\pm \mathrm{SD} ; n=3)$. Conversely, decreasing $\mathrm{K}^{+}$from 12 to $2.4 \mathrm{~mm}$ caused an increase in the $\mathrm{InsP}_{3}$-induced current $(124.3 \pm 11.2 \%$, mean $\pm \mathrm{SD} ; n=3)$. These results suggest that the Ins $\mathrm{P}_{3}$-induced outward current recorded from neuron $\mathrm{R} 12$ is due to an increase in $\mathrm{K}^{+}$conductance but not in $\mathrm{Cl}^{-}$conductance.

Effects of TEA and 4-AP. In Helix neurons (Meech and Standen, 1975) and in Aplysia neurons (Hermann and Gorman, 1979; Hermann and Hartung, 1982), extracellularly applied TEA blocks both $\mathrm{Ca}^{2+}$-activated and voltage-activated outward currents. Figure $7 A$ shows an example of the InsP $\mathrm{P}_{3}$-induced outward current before and after external application of TEA. In $5 \mathrm{~mm}$ TEA, the InsP ${ }_{3}$-induced outward current was reduced to about $21 \%$ of the control. This blocking effect always completely disappeared $12 \mathrm{~min}$ after the cessation of TEA perfusion. On the other hand, external application of $5 \mathrm{~mm}$ 4-aminopyridine (4AP) had no effect on the Ins $\mathrm{P}_{3}$-induced outward current recorded from the same R12 neuron (Fig. $7 B$ ), whereas at similar concentration it blocks a voltage-dependent fast $\mathrm{K}^{+}$current in molluscan neurons (Thompson, 1982).

Effects of external $\mathrm{Ca}^{2+}$ depletion and intracellular injection reversed at ca. $-80 \mathrm{mV}$ suggests that the current was caused by 

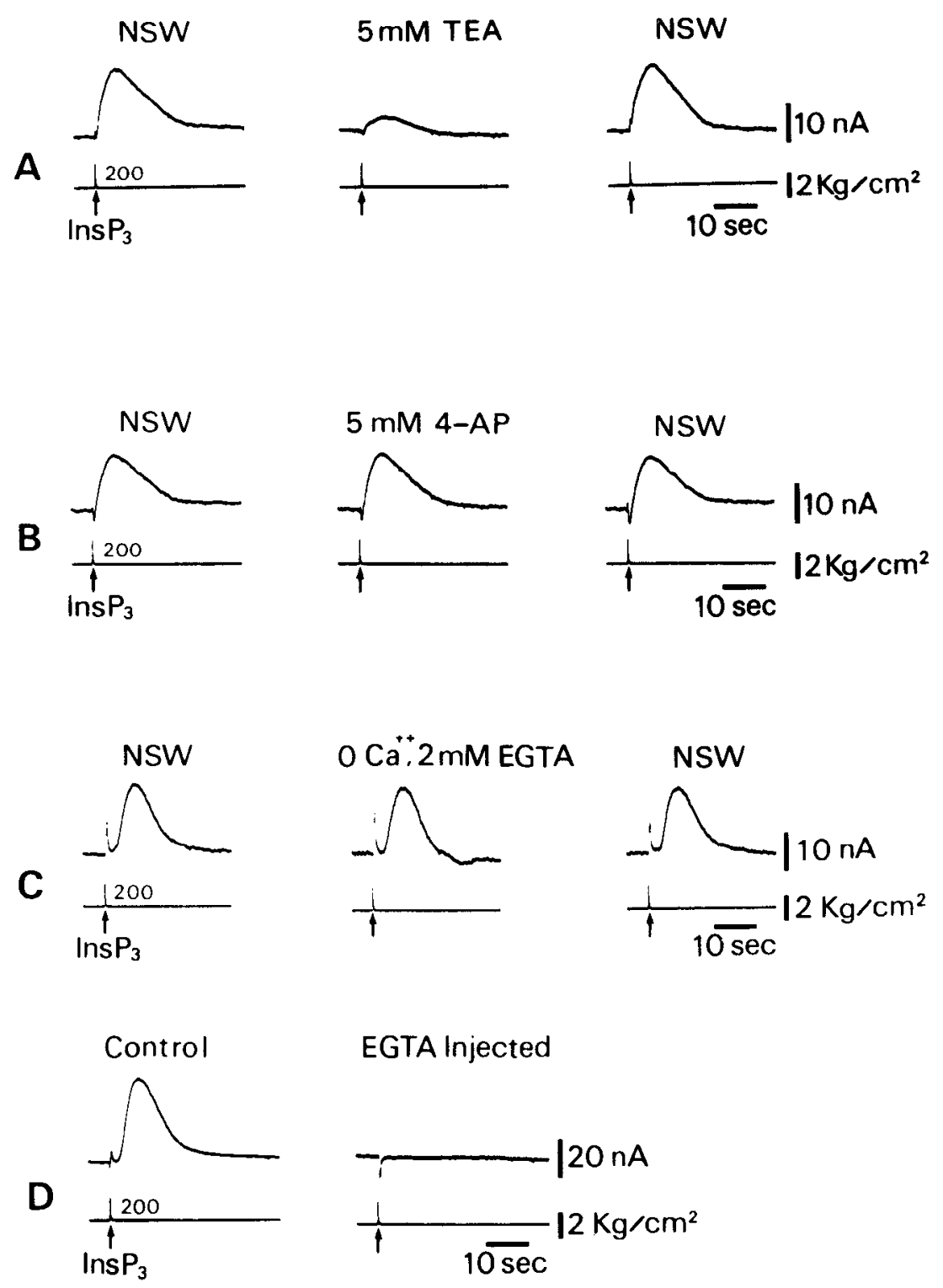

Figure 7. Effects of 5 mM TEA $(A), 5$ mM 4-AP $(B), 0 \mathrm{Ca}^{2+}-2$ mM EGTA seawater $(C)$, and intracellular injection of EGTA $(D)$ on the Ins $\mathrm{P}_{3}$-induced outward current recorded from neuron R12. Holding potential was $-45 \mathrm{mV}$. $\mathrm{InsP}_{3}$ was injected by a single constant pressure pulse $\left(200 \mathrm{msec}, 2 \mathrm{~kg} / \mathrm{cm}^{2}\right)$. A, Left: control; center: nine minutes after $\mathrm{R} 12$ was exposed to $5 \mathrm{mM}$ TEA; right: twelve minutes after washout. $B$, Left: control; center: nine minutes after R 12 was exposed to $5 \mathrm{~mm}$ 4-AP; right: twelve minutes after washout. $C$, Left: control; center: twelve minutes after R12 was exposed to $0 \mathrm{Ca}^{2+}-2$ mM EGTA seawater; right: nineteen minutes after washout. $D$, InsP $_{3}$-induced outward current before (left) and after (right) intracellular injection of EGTA. EGTA was pressure-injected into neuron R12 with seven pulses (each pulse was of $200 \mathrm{msec}$ duration and $1 \mathrm{~kg} / \mathrm{cm}^{2}$ intensity), using 1 barrel of the triple-barreled microelectrode filled with $100 \mathrm{~mm}$ EGTA plus $400 \mathrm{~mm} \mathrm{KCl}$. The calculated final intracellular concentration of EGTA was about $500 \mu \mathrm{M}$. Note that the Ins $\mathrm{P}_{3}$-induced outward current was greatly reduced by $5 \mathrm{~mm}$ TEA and completely abolished by intracellular injection of EGTA. of EGTA. To determine whether the $\operatorname{InsP}_{3}$-induced outward current was dependent on the entry of $\mathrm{Ca}^{2+}$ ions from the extracellular space, the effect of external $\mathrm{Ca}^{2+}$ depletion on the current was studied. A $0 \mathrm{Ca}^{2+}-2$ mM EGTA solution was made by substituting $\mathrm{Mg}^{3+}$ for $\mathrm{Ca}^{3+}$ and adding 2 mM EGTA to artificial Aplysia Ringer's. The $\mathrm{InsP}_{3}$-induced outward current, recorded at a holding potential of $-45 \mathrm{mV}$, persisted in $0 \mathrm{Ca}^{2+}-$ 2 mм EGTA Aplysia Ringer's (Fig. $7 C ; n=4$ ). To further evaluate the contribution of $\mathrm{Ca}^{2+}$-activated conductance changes, 4 R 12 neurons were pressure-injected with EGTA to chelate intracellular calcium ions. When EGTA was pressure-injected into the neuron, the Ins $\mathrm{P}_{3}$-induced outward current was completely abolished and the effect of internal EGTA could not be recovered by washings that lasted up to $1 \mathrm{hr}$ (Fig. $7 D$ ). These results suggest that micropressure injection of Ins $\mathrm{P}_{3}$ into identified neurons of Aplysia can induce an outward $\mathrm{K}^{+}$current activated by increased intracellular free $\mathrm{Ca}^{2+}$ concentration, and that the InsP $\mathrm{P}_{3}$-induced outward current is likely to be a $\mathrm{Ca}^{2+}$ activated $\mathrm{K}^{+}$-conductance increase; however, $\mathrm{Ca}^{2+}$ entry from the extracellular space is not required.

\section{Intracellular injection of $\mathrm{Ca}^{2+}$}

$\mathrm{Ca}^{2+}$-activated $\mathrm{K}^{+}$current can be induced by the influx of $\mathrm{Ca}^{2+}$ through voltage-dependent ion channels in the cell membrane or by direct injection of $\mathrm{Ca}^{2+}$ into the neuron (Meech, 1978). By means of iontophoretic injection of $\mathrm{Ca}^{2+}$ into Aplysia neurons under voltage-clamp conditions it has been shown that $\mathrm{K}^{+}$ ions are the primary charge carriers giving rise to an outward current (Gorman and Hermann, 1979; Hermann and Hartung, 1982). On the other hand, it has been reported that, using pressure injection, $\mathrm{Ca}^{2+}$ ions in Helix neurons activate an inward current followed by a prolonged outward current (Hofmeier and Lux, 1981).

In order to compare the Ins $\mathrm{P}_{3}$-induced outward current with the $\mathrm{Ca}^{2+}$-activated $\mathrm{K}^{+}$current, both $\mathrm{InsP}_{3}$ and $\mathrm{Ca}^{2+}$ ions were micropressure-injected into the same identified neuron. Intracellular injection of $\mathrm{Ca}^{2+}$ always caused a dose-dependent transient outward current associated with a conductance increase in neuron $\mathrm{R} 12$, which was voltage-clamped at a holding potential of $-40 \mathrm{mV}$ (Fig. $8 A$ ). The peak of the outward current responses 
A

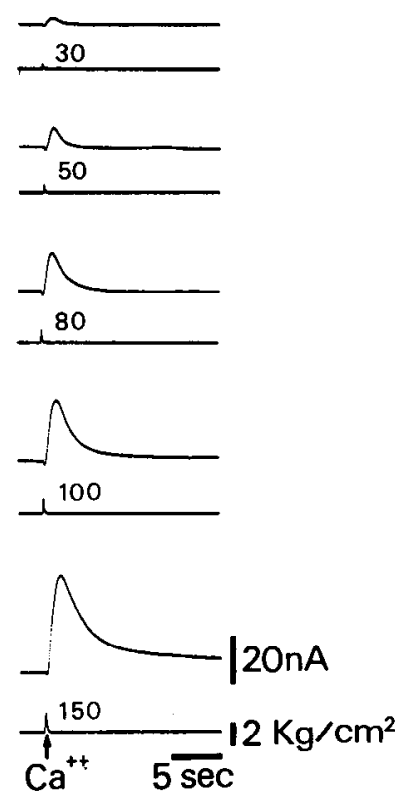

B

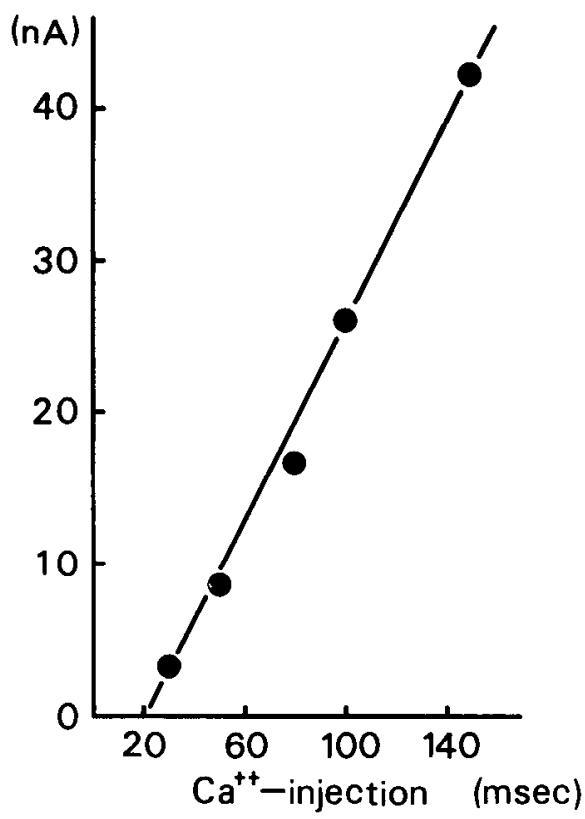

C

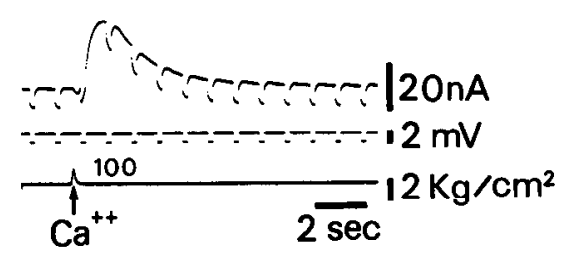

D

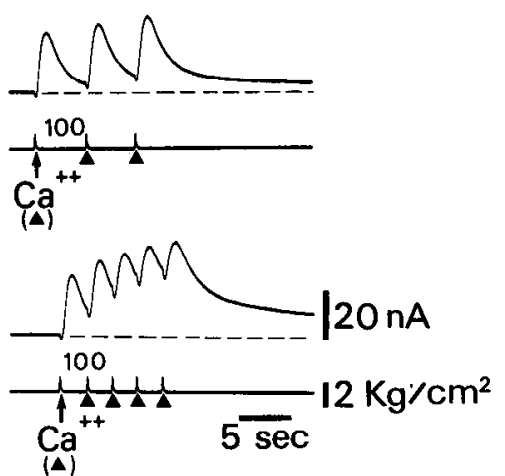

Figure 8. $\mathrm{Ca}^{2+}$-activated outward currents induced by $\mathrm{CaCl}_{2}$ injections of different durations at a constant pressure intensity $\left(2 \mathrm{~kg} / \mathrm{cm}^{2}\right)$ into neuron $\mathrm{R} 12$. Holding potential, $-40 \mathrm{mV}$. $A$, Membrane current responses to pressure-injected $\mathrm{CaCl}_{2}$ at different pulse durations. $B$, Plot of data in $A$; relationship between the duration of pressure for the $\mathrm{CaCl}_{2}$ injection and the peak of the $\mathrm{Ca}^{2+}$-activated outward current. $C$, Ca ${ }^{2+}$-activated outward current associated with an increase in membrane conductance. Same nomenclature as in Figure $1 B$. CaCl ${ }_{2}$ was injected by a single constant pressure pulse $\left(100 \mathrm{msec}, 2 \mathrm{~kg} / \mathrm{cm}^{2}\right) . D$, Effect of repetitive injection of $\mathrm{CaCl}_{2}$ into neuron $\mathrm{R} 12 . \mathrm{CaCl}_{2}$ was injected by constant pulse (100 msec, 2 $\left.\mathrm{kg} / \mathrm{cm}^{2}\right)$ every $5 \mathrm{sec}($ top $)$ or every $2.5 \mathrm{sec}\left(\right.$ bottom) into the same neuron. Note that the peak outward current activated by CaCl${ }_{2}$ injection rose linearly with the duration of the pressure pulse for the $\mathrm{CaCl}_{2}$ injection and that repeated injection of $\mathrm{CaCl}_{2}$ caused a summation.

rose linearly with the duration of the $\mathrm{Ca}^{2+}$ injection. The straight line fitted to the experimental points (Fig. $8 B$ ) had a slope of $33 \mathrm{nA}$ per $100 \mathrm{msec}-i n j e c t e d \mathrm{Ca}^{2+}$ load, using a constant pressure intensity of $2 \mathrm{~kg} / \mathrm{cm}^{2}$. The line did not pass through the origin, which indicates that a certain minimum number of $\mathrm{Ca}^{2+}$ ions must be injected in order to activate the outward current. With a single injection (pressure pulse duration, $100 \mathrm{msec}$; pressure intensity, $2 \mathrm{~kg} / \mathrm{cm}^{2}$ ), the calculated concentration of $\mathrm{Ca}^{2+}$ in neuron $\mathrm{R} 12(300 \mu \mathrm{m}$ diameter; cell volume, $14.2 \mathrm{nl})$ was 5 $\mu \mathrm{M}$ when the injection electrode was filled with $10 \mathrm{mM} \mathrm{CaCl}$ (see Methods in Hara et al., 1985). With increasing duration of the injection pressure pulse, the rise of the outward current was faster and the duration of the outward current prolonged.

Repetitive injections of $\mathrm{Ca}^{2+}$ at relatively short intervals lead to overlap and/or summation (Fig. $8 D$ ). Both the amplitude and the delay from the beginning of injection to the onset of the $\mathrm{Ca}^{2+}$-activated outward current were dependent on the position of the injection electrode (similar to the findings for Ins $\mathrm{P}_{3}$ injections). Larger amplitude and shorter delay of the $\mathrm{Ca}^{2+}$-activated currents were recorded when the injection electrode was positioned nearer the cell membrane than the center of the soma.

\section{Ionic mechanism of the $\mathrm{Ca}^{2+}$-activated outward current}

Effect of holding potential. The $\mathrm{Ca}^{2+}$-activated outward current was typically associated with an apparent increase in the membrane conductance, as illustrated in Figures $8 \mathrm{C}$ and $9 \mathrm{~A}$. At the peak of the $\mathrm{Ca}^{2+}$-activated outward current, membrane input conductance increased from $170 \%$ (Fig. $8 \mathrm{C}$ ) to $550 \%$ of the control (Fig. 9A). Figure $9 C$ shows a plot of the $\mathrm{Ca}^{2+}$-activated outward current recorded from neuron $\mathrm{R} 12$ versus membrane holding potential. The relationship between the $\mathrm{Ca}^{2+}$-activated outward current amplitude and holding potential is not linear. The outward current decreased at holding potentials more hyperpolarized than $-45 \mathrm{mV}$ and disappeared near the predicted equilibrium potential for $\mathrm{K}^{+}$ions $(-80 \mathrm{mV})$. These data confirm the finding of others (Hermann and Hartung, 1982; Kehoe, 1985) that the increase in $\mathrm{K}^{+}$conductance induced by intracellular injection of $\mathrm{Ca}^{2+}$ ions into certain molluscan neurons is highly voltage-dependent, disappearing at hyperpolarizing potentials.

Effects of TEA, 4- $A P$, and high $K^{+}{ }_{0}$. Figure $10 \mathrm{~A}$ presents an example of the $\mathrm{Ca}^{2+}$-activated outward current before and after external application of TEA. In $5 \mathrm{mM}$ TEA, the $\mathrm{Ca}^{2+}$-activated outward current was reduced to $23.8 \%$ of the control. This blocking effect always disappeared completely $12 \mathrm{~min}$ after the cessation of TEA perfusion. On the other hand, external application of $5 \mathrm{~mm}$ 4-AP had no effect on the $\mathrm{Ca}^{2+}$-activated outward current recorded from the same neuron $\mathrm{R} 12$ (Fig. 10B). Increasing $\mathrm{K}^{+}{ }_{0}$ from 12 to $24 \mathrm{mM}$ caused a marked decrease in the $\mathrm{Ca}^{2+}$-activated outward current recorded from $\mathrm{R} 12$ (62.3 \pm $8.7 \%$ of the control, mean $\pm \mathrm{SD} ; n=3$ ) (Fig. $10 \mathrm{C}$ ). In another experiment, in which both $\mathrm{Ca}^{2+}$ and $\mathrm{InsP}_{3}$ were successfully injected into neuron $\mathrm{R} 12$, bath-applied TEA, at a concentration of $2 \mathrm{~mm}$ for 6-9 min, reduced the $\mathrm{Ca}^{2+}$-activated outward current to $61.2 \%$ of the control and the $\mathrm{InsP}_{3}$-induced outward current to $44.4 \%$ of the control (Fig. $11 B$ ). We have not performed a sufficient number of experiments to determine whether the difference between the reduction of the $\mathrm{Ca}^{2+}$ and $\mathrm{InsP}_{3}$ re- 
A

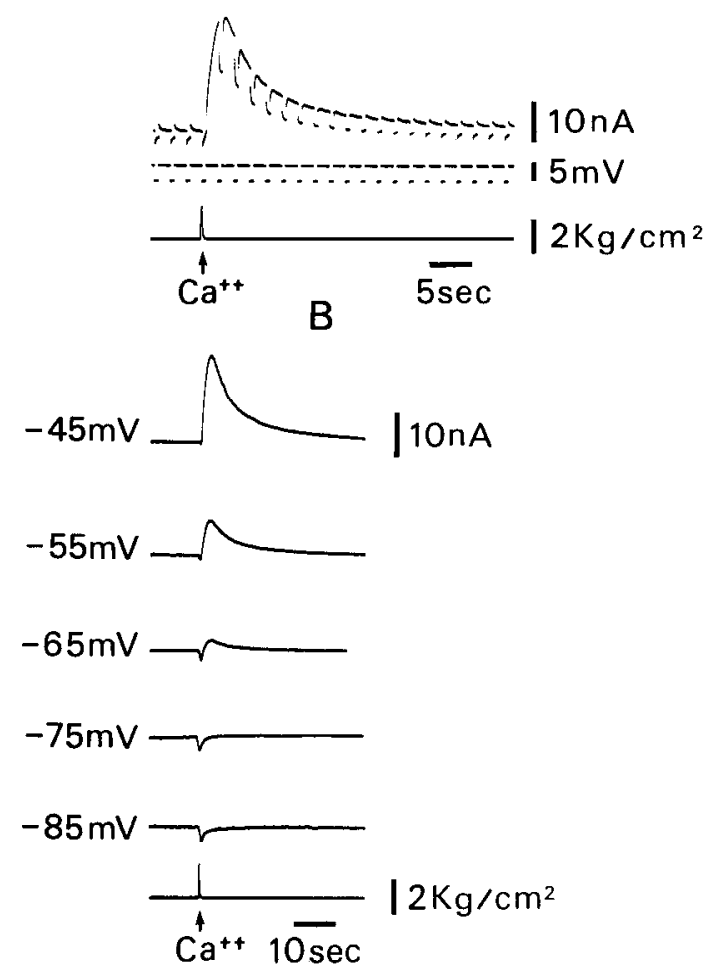

C

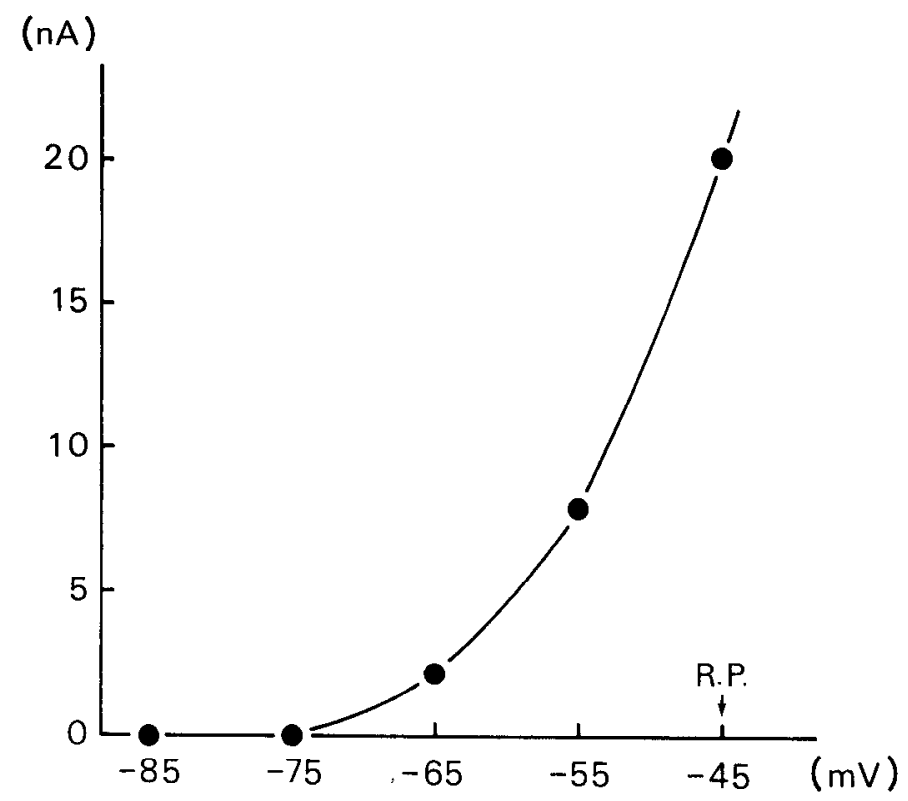

Figure 9. $\mathrm{Ca}^{2+}$-activated outward current associated with an increase in membrane conductance $(A)$, $\mathrm{Ca}^{2+}$-activated outward currents at different holding potentials $(B)$, and a plot of the voltage sensitivity of these currents recorded from neuron $\mathrm{R} 12(C) \mathrm{CaCl}_{2}$ was injected by a single constant pressure pulse $\left(200 \mathrm{msec}, 2 \mathrm{~kg} / \mathrm{cm}^{2}\right)$. Holding potential was $-45 \mathrm{mV}$ in $A$. Note that the $\mathrm{Ca}^{2+}$-activated outward current decreased at hyperpolarized holding potentials more negative than $-45 \mathrm{mV}$, disappeared near the predicted equilibrium potential for $\mathrm{K}^{+}$ions $(-80 \mathrm{mV})$, and was associated with an apparent increase in membrane conductance.

sponses is significant. However, in separate experiments, the percentages of reduction were always quite similar (see above), which suggests that Ins $\mathrm{P}_{3}$ and $\mathrm{Ca}^{2+}$ modulate the same membrane channel. On the other hand, both $\mathrm{Ca}^{2+}$-activated and Ins $\mathrm{P}_{3}$-induced outward currents recorded from the same neuron R12 were not influenced by bath application of 4-AP at a concentration of $5 \mathrm{~mm}$ for $6-9 \mathrm{~min}$ (Fig. 11D). This suggests that brief micropressure injection of InsP $\mathrm{P}_{3}$ into neuron R12 of $A p l y$ sia can induce an outward current associated with an increase in $\mathrm{K}^{+}$conductance, and that the current is identical to the $\mathrm{Ca}^{2+}$ activated $\mathrm{K}^{+}$outward current produced by $\mathrm{Ca}^{2+}$ injection into the same neuron, judging from the ionic mechanism and pharmacological properties.

\section{Comparison between the InsP $P_{3}$-induced outward current and} the $\mathrm{Ca}^{2+}$-activated outward current

To evaluate further the properties of the Ins $\mathrm{P}_{3}$-induced outward current and of the $\mathrm{Ca}^{2+}$-activated outward current, InsP $\mathrm{P}_{3}$ and $\mathrm{CaCl}_{2}$ were micropressure-injected into the same identified neuron $\mathrm{R} 12$ using 2 different barrels of a triple-barreled microelectrode. First, InsP $\mathrm{P}_{3}$ was injected into the neuron using a single constant pressure pulse with a comparatively short duration; InsP $P_{3}$-induced outward current was recorded as a "control" response. After sufficient time $(30 \mathrm{sec})$ had passed after the first injection of Ins $\mathrm{P}_{3}, \mathrm{CaCl}_{2}$ was injected into the same neuron using the other barrel. The amplitude of the $\mathrm{Ca}^{2+}$-activated outward current was made identical to that of the InsP $\mathrm{P}_{3}$-induced outward current by adjusting the duration of the pressure pulse for the $\mathrm{Ca}^{2+}$ injection (Fig. 12A,a,b). Second, the interval between the first injection of $\operatorname{InsP}_{3}$ and subsequent injection of $\mathrm{Ca}^{2+}$ was varied (Fig. 12A,c-g). Pressure-injected InsP $P_{3}$, followed by $\mathrm{Ca}^{2+}$ injection at short intervals (less than $3 \mathrm{sec}$ ), caused an apparent increase in the outward $\mathrm{Ca}^{2+}$-induced current as compared to that induced by individual $\mathrm{Ca}^{2+}$ injections (Fig. 12A,c-f). This increase could be due to summation or, alternatively, prior InsP might potentiate a subsequent response to $\mathrm{Ca}^{2+}$ injection. Figure $12, B, C$ supports the hypothesis that there may be some potentiation. For example, pressure-injected $\mathrm{Ca}^{2+}$ followed by InsP injection at short intervals (less than $2.5 \mathrm{sec}$ ) did not cause any increase in the outward current induced by $\operatorname{InsP}_{3}$ (Fig. 12B,c,d). Furthermore, in another R 12 neuron the effects were clearly distinguishable from simple summation (Fig. 12C). In this example, $\mathrm{Ca}^{2+}$ injection after preinjection of $\operatorname{InsP}_{3}$ at short intervals $(2.5 \mathrm{sec})$ produced a response that was larger than that produced by $\mathrm{Ca}^{2+}$ injection alone. These results indicate that the $\mathrm{Ca}^{2+}$-activated outward current induced by injection of $\mathrm{CaCl}_{2}$ is potentiated after preinjection of Ins $\mathrm{P}_{3}$ at short intervals. This potentiation might result from the addition of injected $\mathrm{Ca}^{2+}$ to the intracellular free $\mathrm{Ca}^{2+}$ released from stores by $\mathrm{InsP}_{3}$.

\section{Effects of $\mathrm{W}-7$ on the Ins $P_{3}$-induced and $\mathrm{Ca}^{2+}$-activated outward currents}

Calmodulin is the common $\mathrm{Ca}^{2+}$-binding protein that mediates ubiquitous cellular responses to increases in intracellular $\mathrm{Ca}^{2+}$ (Kakiuchi et al., 1970; Cheung, 1981; Weiss et al., 1982). In the bag cell neurons of Aplysia, calmodulin inhibitors such as trifluoperazine (TFP) and $N$-(6-aminohexyl)-5-chloro-1-naphthalene sulfonamide (W-7) have been shown to inhibit calcium/ 

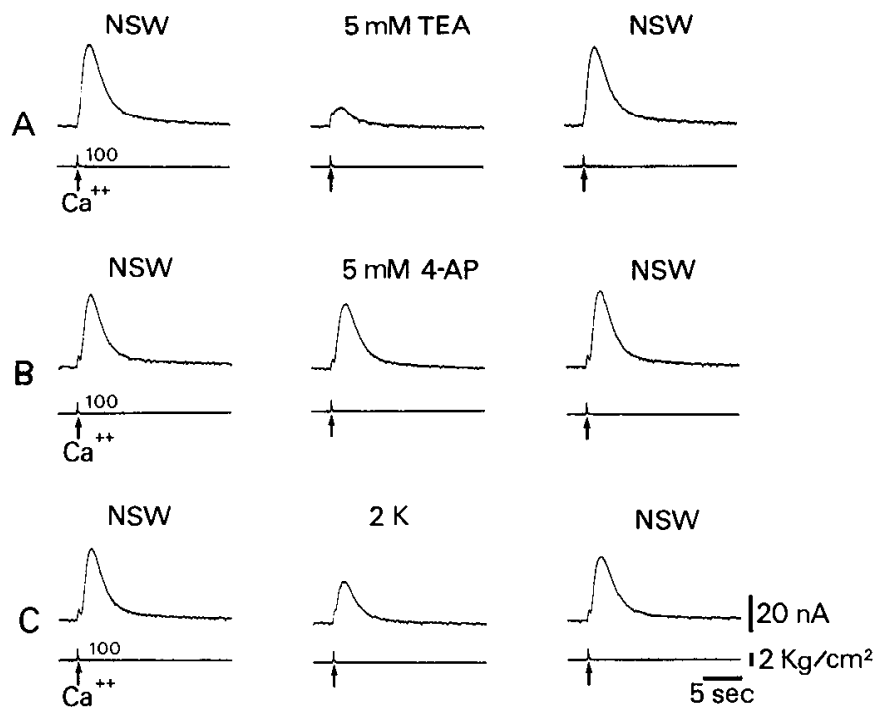

Figure 10. Effects of $5 \mathrm{mM}$ TEA $(A), 5 \mathrm{~mm}$ 4-AP $(B)$, and high-K ${ }^{+}$ seawater $(C)$ on the $\mathrm{Ca}^{2+}$-activated outward current recorded from neuron $\mathrm{R} 12$. Holding potential was $-40 \mathrm{mV}$. $\mathrm{CaCl}_{2}$ was injected by a single constant pressure pulse $\left(100 \mathrm{msec}, 2 \mathrm{~kg} / \mathrm{cm}^{2}\right)$. A, Left: control; center: nine minutes after R12 was exposed to $5 \mathrm{mM}$ TEA; right: twelve minutes after washout. $B$, Left: control; center: nine minutes after $\mathrm{R} 12$ was exposed to $5 \mathrm{~mm}$ 4-AP; right: twelve minutes after washout. $C$, Left: control; center: six minutes after $\mathrm{R} 12$ was exposed to high $\mathrm{K}^{+}{ }_{0}(2 \times$ normal $\mathrm{K}^{+}$) seawater; right: nine minutes after washout. Note that the $\mathrm{Ca}^{2+}$-activated outward current was greatly reduced by $5 \mathrm{mM}$ TEA.

calmodulin-dependent enzymes as well as the calcium-phospholipid-dependent protein kinase in vitro (DeRiemer et al., 1983, 1984). Therefore, we studied the effects of W-7 on both the InsP $\mathrm{P}_{3}$-induced and $\mathrm{Ca}^{2+}$-activated outward current recorded from the same R12 neuron.

Extracellular application of W-7 (20-50 $\mu \mathrm{M})$ reduced both the Ins $\mathrm{P}_{3}$-induced and the $\mathrm{Ca}^{2+}$-activated outward currents (Fig. 13). The effect of W-7 on both these currents was only partially reversible, even after prolonged ( $>1 \mathrm{hr}$ ) washings. In another neuron R12 from a different preparation, bath-applied W-7, at a concentration of $10 \mu \mathrm{M}$ for $6 \mathrm{~min}$, reduced the $\operatorname{InsP}_{3}$-induced and $\mathrm{Ca}^{2+}$-activated outward currents to 29.1 and $46.1 \%$ of their control values, respectively (not illustrated). Figure 14 shows the time course of the inhibitory effects of $\mathrm{W}-7$ on both the Ins $\mathrm{P}_{3}$-induced outward current $(A)$ and the $\mathrm{Ca}^{2+}$-activated outward current $(B)$, recorded from the same neuron R12. Bathapplied $\mathrm{W}-7$ at a concentration of $50 \mu \mathrm{M}$ for $13 \mathrm{~min}$ reduced the Ins $\mathrm{P}_{3}$-induced outward current to $17.3 \%$ of the control and the $\mathrm{Ca}^{2+}$-activated outward current to $4.6 \%$ of the control. The maximal inhibitory effects of W-7 on these outward currents were obtained several minutes after washout had begun, and the effects were again only partially reversible, even after prolonged ( $>1 \mathrm{hr}$ ) washings.

\section{Discussion}

The present study demonstrates that brief micropressure injection of Ins $\mathrm{P}_{3}$ into identified neurons (R9-R12) of Aplysia induces an outward current associated with an increase in $\mathrm{K}^{+}$conductance, and the current shows the same ionic and pharmacological properties as those evoked by $\mathrm{Ca}^{2+}$ injection into the same neuron. Furthermore, the Ins $\mathrm{P}_{3}$-induced outward current is activated by the increased $\mathrm{Ca}^{2+}$ concentration resulting from mobilization of $\mathrm{Ca}^{2+}$ from intracellular stores, but not from $\mathrm{Ca}^{2+}$
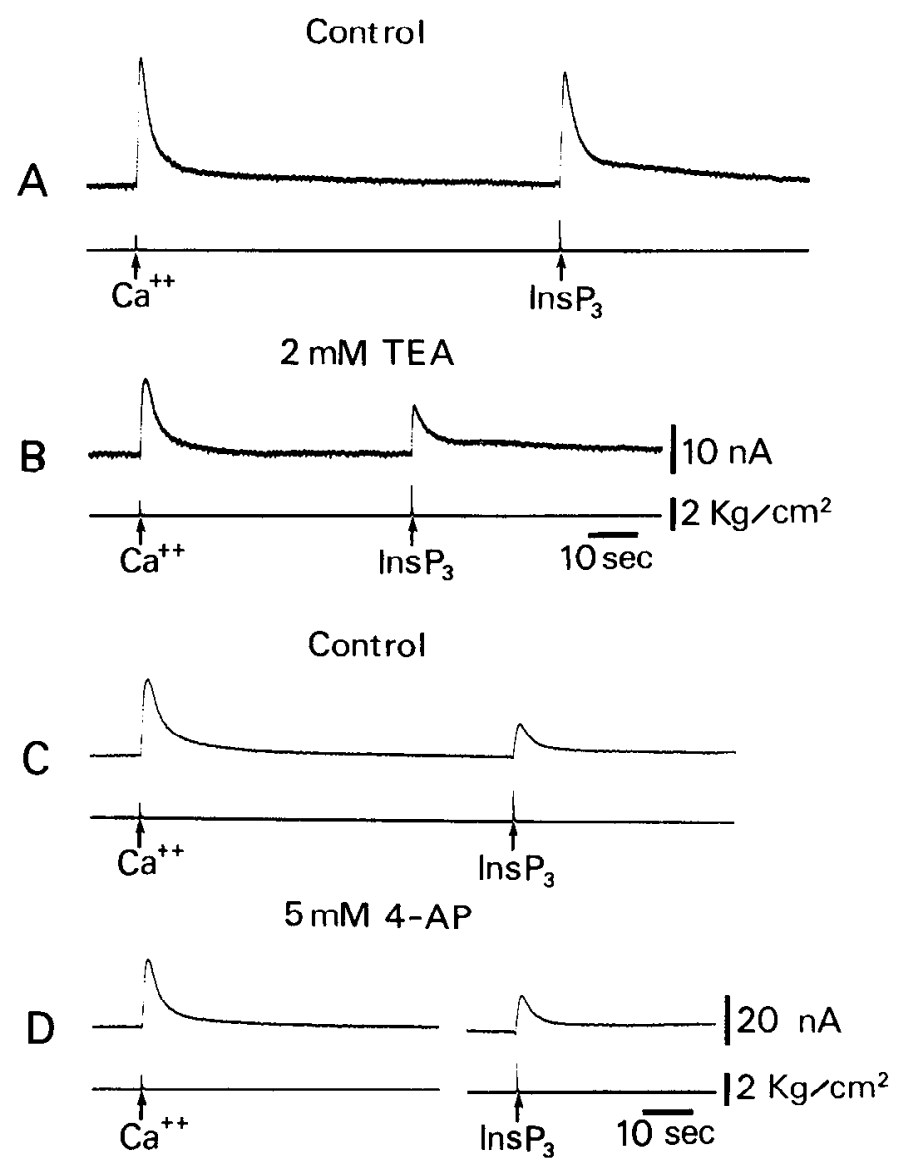

Figure 11. Effects of $2 \mathrm{mM}$ TEA on the $\mathrm{Ca}^{2+}$-activated and the $\mathrm{InsP}_{3}$ induced outward current $(B)$, and effects of $5 \mathrm{~mm} 4-\mathrm{AP}$ on the $\mathrm{Ca}^{2+}$ activated and the Ins $P_{3}$-induced outward current $(D)$ recorded from the same neuron $\mathrm{R} 12$. Holding potential was $-35 \mathrm{mV} . \mathrm{CaCl}_{2}$ was injected by a single constant pressure pulse $\left(70 \mathrm{msec}, 2 \mathrm{~kg} / \mathrm{cm}^{2}\right)$ using 1 barrel of the triple-barreled microelectrode. Ins $P_{3}$ was injected by a constant pressure pulse $\left(170 \mathrm{msec}, 2 \mathrm{~kg} / \mathrm{cm}^{2}\right)$ using a second barrel of the microelectrode. $A, C$, Control outward current responses to $\mathrm{CaCl}_{2}$ and InsP $_{3}$ injection. $B$, Six to nine minutes after R12 was exposed to $2 \mathrm{mM}$ TEA. $D$, Six to nine minutes after R12 was exposed to $5 \mathrm{~mm}$ 4-AP. Note that both the $\mathrm{Ca}^{2+}$-activated outward current and the InsP ${ }_{3}$-induced outward current were inhibited by bath-applied TEA.

in the extracellular space. Both the Ins $P_{3}$-induced outward current and the $\mathrm{Ca}^{2+}$-activated outward current in the neuron may involve a common mechanism mediated by the calcium/calmodulin-dependent enzyme or the calcium-phospholipid-dependent protein kinase for the opening of a specific $\mathrm{K}^{+}$channel.

The hypothesis that the $\operatorname{InsP}_{3}$-induced outward current is due to an increase in $\mathrm{K}^{+}$conductance activated by an increased $\mathrm{Ca}^{2+}$ concentration via mobilization of $\mathrm{Ca}^{2+}$ from intracellular storage sites is supported by the following observations: (1) The Ins $\mathrm{P}_{3}$-induced outward current is sensitive to changes in the extracellular $\mathrm{K}^{+}$concentration, but not to the extracellular $\mathrm{Cl}^{-}$ concentration. (2) The Ins $\mathrm{P}_{3}$-induced outward current has a reversal potential near the potassium equilibrium potential $(-80$ $\mathrm{mV}$ ). (3) Extracellular $2 \mathrm{~mm}$ EGTA in $0 \mathrm{Ca}^{2+}$ does not affect the Ins $\mathrm{P}_{3}$-induced outward current; however, intracellularly injected EGTA completely blocks the current. (4) The InsP $\mathrm{P}_{3}$-induced outward current is identical to a $\mathrm{Ca}^{2+}$-activated $\mathrm{K}^{+}$outward current induced by injection of $\mathrm{CaCl}_{2}$ that was recorded from the same neuron, according to ionic dependency and phar- 


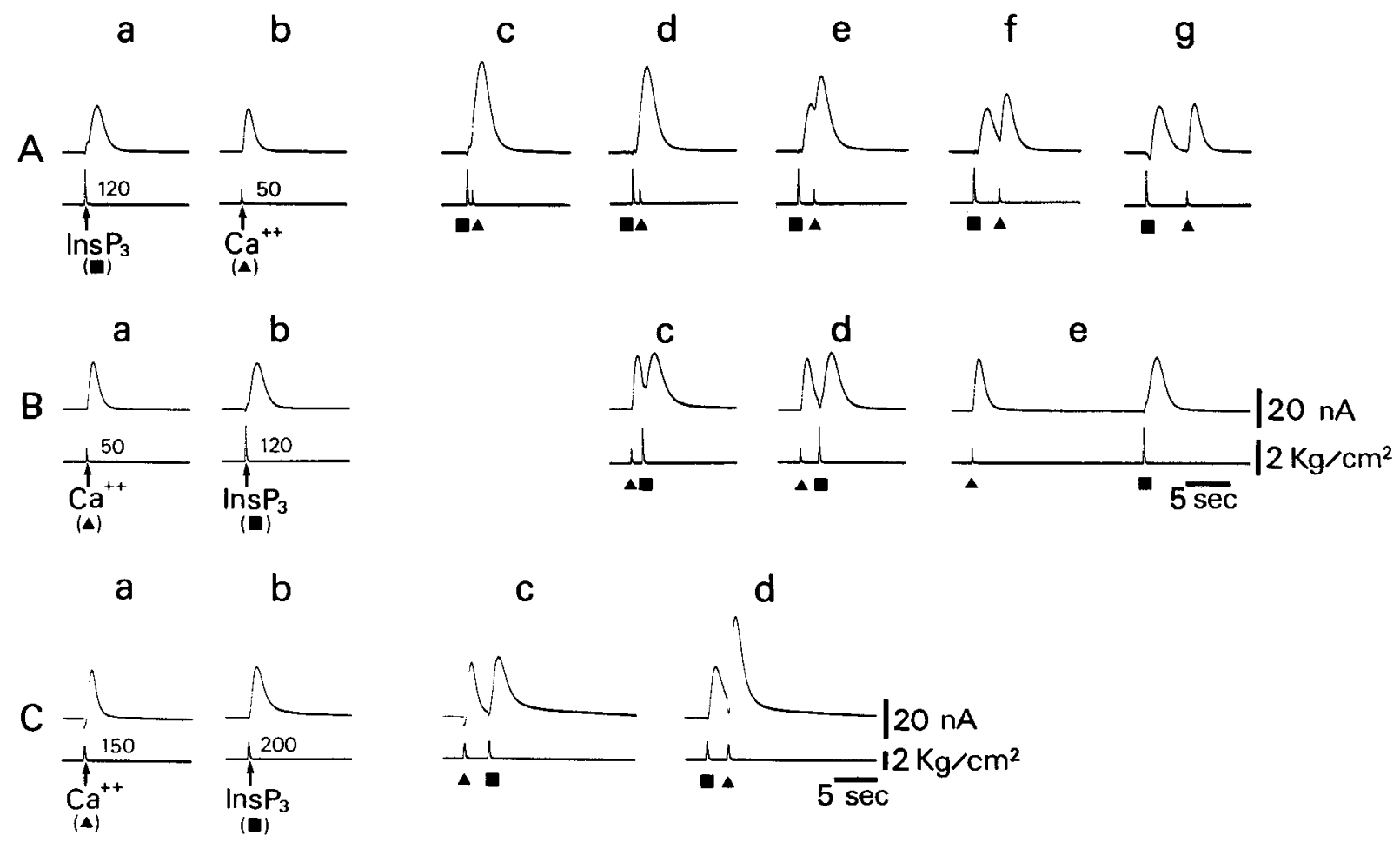

Figure 12. Comparison of the Ins $\mathrm{P}_{3}$-induced outward current with the $\mathrm{Ca}^{2+}$-activated outward current recorded from the same neuron $\mathrm{R} 12$ ( $A$, $B$ ) and from another neuron $\mathrm{R} 12$ from a different preparation $(C)$. Ins $\mathrm{P}_{3}$ was injected using $\mathbf{l}$ barrel of the triple-barreled microelectrode and $\mathrm{CaCl}_{2}$ was injected using the other barrel of the microelectrode. Ins $\mathrm{P}_{3}$ was injected by a single constant pressure pulse $\left(120 \mathrm{msec}, 2 \mathrm{~kg} / \mathrm{cm}^{2}\right.$ in $A$ and $B$; $200 \mathrm{msec}, 2 \mathrm{~kg} / \mathrm{cm}^{2}$ in $C$ ). $\mathrm{CaCl}_{2}$ was injected by a single constant pressure pulse ( $50 \mathrm{msec}, 2 \mathrm{~kg} / \mathrm{cm}^{2}$ in $A$ and $B ; 150 \mathrm{msec}, 2 \mathrm{~kg} / \mathrm{cm}^{2}$ in $C$ ). Holding potential was $-45 \mathrm{mV}$ in $A$ and $B,-40 \mathrm{mV}$ in $C . A, a, B, b, C, b$, Control outward current responses to InsP ${ }_{3}$ injection; $A, b, B, a, C, a, O$ Outward current responses to $\mathrm{CaCl}_{2}$ injection made to be of the same amplitude as that of the Ins $\mathrm{P}_{3}$-induced response by adjusting the pressure pulse duration (see text). A,c-g, Outward current responses to paired injection of $\mathrm{InsP}_{3}$ (closed squares) followed by $\mathrm{CaCl}_{2}($ closed triangles) at different intervals. $B, c-e$, Outward current responses to paired injections of $\mathrm{CaCl}_{2}$ (closed triangles) followed by InsP $\mathrm{P}_{3}$ (closed squares) at different intervals. C,c, Outward current responses to a paired injection of $\mathrm{CaCl}_{2}$ (closed triangle) followed by InsP $\mathrm{P}_{3}$ (closed square) at short intervals (2.5 sec). $C$, $d$, Outward current response to a paired injection of $\mathrm{InsP}_{3}$ (closed square) followed by $\mathrm{CaCl}_{2}$ (closed triangle) at short intervals ( 2.5 sec). Note that pressureinjected InsP $\mathrm{P}_{3}$ followed by $\mathrm{CaCl}_{2}$ injection at short intervals caused a large increase in the outward current.

macological properties (Hermann and Gorman, 1979; Hermann and Hartung, 1982).

cAMP has been shown to be the likely mediator of many transmitter-induced diminutions in $\mathrm{K}^{+}$conductance (Castellucci et al., 1980; Deterre et al., 1982; Siegelbaum et al., 1982). In the report of Kaczmarek and Strumwasser (1984), cAMP appears to diminish a $\mathrm{Ca}^{2+}$-activated $\mathrm{K}^{+}$conductance as well as the rapidly inactivating, voltage-gated A-current (Strong, 1984) in the bag cells of Aplysia. On the other hand, serotonin, dopamine, and stimulation of the branchial nerve all cause the R15 neuron of Aplysia to hyperpolarize and stop bursting (Drummond et al., 1980). A series of biochemical, pharmacological, and electrophysiological experiments have satisfied all the criteria (Greengard, 1978) necessary to implicate cAMP as an intracellular second messenger for this response (Drummond et al., 1980). Furthermore, in the Aplysia ILD (inhibition of long duration) neurons, forskolin, a potent activator of adenylate cyclase (Seamon and Daly, 1982) mimics a dopamine-induced outward current and cAMP may play a role as second messenger mediating the dopamine-induced $\mathrm{K}^{+}$conductance increase (Sawada et al., 1980).

In addition to cAMP, another series of intracellular second messengers has recently been shown to function as transducing agents, relaying information from the external cell surface to intracellular enzymes for the purpose of modifying cell function and neuronal transmission. There have been 2 recent advances in our knowledge of intracellular signaling mechanisms. One of these was the discovery of a $\mathrm{Ca}^{2+}$ - and phospholipid-dependent protein kinase, or protein kinase C (Nishizuka, 1984), which has a greatly increased affinity for $\mathrm{Ca}^{2+}$ and enhanced activity in the presence of diacylglycerol. The other was the demonstration that InsP $\mathrm{P}_{3}$ causes $\mathrm{Ca}^{2+}$ release from a vesicular, nonmitochondrial pool (Streb et al., 1983; Burgess et al., 1984; Joseph et al., 1984) and has the attributes of a $\mathrm{Ca}^{2+}$-mobilizing second messenger.

Hydrolysis of PI- $\mathrm{P}_{2}$ by phospholipase $\mathrm{C}$ produces diacylglycerol and InsP $\mathrm{P}_{3}$, and these products play an essential role in cell activity as second messengers. In particular, Ins $\mathrm{P}_{3}$ is known to release $\mathrm{Ca}^{2+}$ from storage sites in a variety of cell types (Berridge, 1984; Berridge and Irvine, 1984).

Recently Oron and his collaborators (1985) demonstrated that the direct intracellular injection of InsP $\mathrm{P}_{3}$ into a Xenopus oocyte mimicked a muscarinic depolarizing chloride current. In addition, the intracellular pressure injection of Ins $\mathrm{P}_{3}$ into Limulus photoreceptors (Brown et al., 1984; Fein et al., 1984) and salamander rods (Waloga and Anderson, 1985) has been shown to mimic several aspects of the light-induced response. Furthermore, the effects of InsP $P_{3}$, on the electrical properties of the peptidergic bag cell neurons of Aplysia have been investigated by Fink and her coworkers (1985), and they reported that in- 


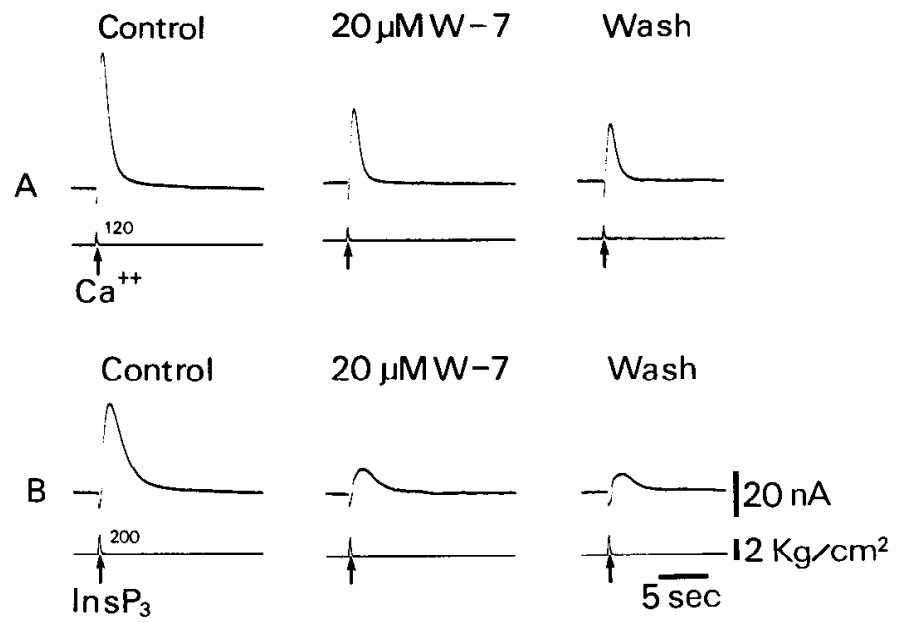

Figure 13. Inhibitory effects of $20 \mu \mathrm{M} \mathrm{W}-7$ on the $\mathrm{Ca}^{2+}$-activated outward current $(A)$ and the InsP $\mathrm{P}_{3}$-induced outward current $(B)$, recorded from the same neuron $\mathrm{R} 12$. Holding potential was $-40 \mathrm{mV} . \mathrm{CaCl}_{2}$ was injected by a single constant pressure pulse $\left(120 \mathrm{msec}, 2 \mathrm{~kg} / \mathrm{cm}^{2}\right)$ using 1 barrel of the triple-barreled microelectrode. $\operatorname{InsP}_{3}$ was injected by a single constant pressure pulse ( $\left.200 \mathrm{msec}, 2 \mathrm{~kg} / \mathrm{cm}^{2}\right)$ using another barrel of the microelectrode. $A$ and $B$, Left: control outward current responses to $\mathrm{CaCl}_{2}$ and InsP $\mathrm{P}_{3}$ injection; center: six to nine minutes after $\mathrm{R} 12$ was exposed to W-7; right: forty to forty-five minutes afer washout. Note that both the $\mathrm{Ca}^{2+}$-activated and Ins $\mathrm{P}_{3}$-induced outward current were inhibited in the presence of W-7 at low concentrations and that these inhibitory effects were only partially reversible, even after prolonged $(>1 \mathrm{hr}$ ) washings.

tracellularly injected Ins $P_{3}$ hyperpolarized the bag cell membrane and caused a reduction in the amplitude of action potentials evoked by depolarizing current.

The results presented in this study strongly suggest that $\mathrm{Ca}^{2+}$ is the intracellular mediator of the InsP $\mathrm{P}_{3}$-induced outward current in identified neurons of Aplysia kurodai. This suggestion is supported by the following facts: (1) intracellularly injected $\mathrm{Ca}^{2+}$ induces a dose-dependent $\mathrm{K}^{+}$conductance increase similar to that produced by $\mathrm{Ins}_{3}$; (2) intracellular $\mathrm{Ca}^{2+}$ depletion by means of EGTA injection eventually inhibits the $\mathrm{InsP}_{3}$-induced outward current; (3) the calmodulin inhibitor W-7 (Hidaka et al., 1981 ) inhibits the $\mathrm{K}^{+}$outward current evoked by both $\mathrm{InsP}_{3}$ and by $\mathrm{CaCl}_{2}$ injection. The efficacy of EGTA in buffering the internal $\mathrm{Ca}^{2+}$ was verified by demonstrating that the EGTA completely eliminated the $\mathrm{Ca}^{2+}$-dependent $\mathrm{K}^{+}$current activated by depolarization of neurons in the pleural ganglion of Aplysia (Kehoe and Marty, 1980; Kehoe, 1985).

Because the InsP $\mathrm{P}_{3}$-induced outward current is persistent in 0 $\mathrm{Ca}^{2+}-2$ mM EGTA seawater, it was concluded that most of the $\mathrm{Ca}^{2+}$ ions required for the InsP $\mathrm{P}_{3}$-induced $\mathrm{K}^{+}$outward current are mobilized from intracellular storage sites. It has been reported that the release of intracellular $\mathrm{Ca}^{2+}$ does not require influx of extracellular $\mathrm{Ca}^{2+}$ for the activation of smooth muscle by transmitter (Bond et al., 1984) and that $\mathrm{Ca}^{2+}$ release is not influenced by inhibitors of mitochondrial oxidative phosphorylation (Somlyo et al., 1985). Furthermore, in Xenopus oocytes, Dascal and his coworkers (1985) have demonstrated that neither external $\mathrm{Ca}^{2+}$ depletion nor the $\mathrm{Ca}$ channel blockers nifedipine and $\mathrm{Mn}^{2+}$ were able to fully block the $\mathrm{Cl}^{-}$current evoked by $\mathrm{ACh}$, and they concluded that most of the $\mathrm{Ca}^{2+}$ ions required for this current were mobilized from intracellular stores. Recent electron-probe analytic studies have directly demonstrated that the sarcoplasmic reticulum (SR) is the source of intracellular
$\mathrm{Ca}^{2+}$ released by norepinephrine in the rabbit main pulmonary artery (Kowarski et al., 1985). It has recently been reported as well that InsP ${ }_{3}$ releases $\mathrm{Ca}^{2+}$ from the sarcoplasmic reticulum of vascular smooth muscle (Suematsu et al., 1984) and the cardiac sarcoplasmic reticulum of canine ventricular muscle (Hirata et al., 1984).

It is well established that $\mathrm{Ca}^{2+}$ is important in regulating $\mathrm{K}^{+}$ conductance increases in molluscan neurons (Meech 1978; Hermann and Hartung, 1982; Deitmer and Eckert, 1985) and the $\mathrm{Cl}^{-}$conductance increase in Xenopus oncytes (Dascal et al., 1985).

When, in the same identified R12 neuron of Aplysia, the $\mathrm{InsP}_{3}$-induced outward currents are compared with the $\mathrm{Ca}^{2+}$ activated outward current, bath-applied TEA at $2 \mathrm{~mm}$ reduced these currents to about $40-60 \%$ of their control values, but neither the InsP $\mathrm{P}_{3}$-induced nor the $\mathrm{Ca}^{2+}$-activated outward current was influenced by bath-applied 4-AP at $5 \mathrm{~mm}$ (Fig. 11, $B$, $D$ ). These data suggest that a parallel can be drawn between the InsP $\mathrm{P}_{3}$-induced outward current and the $\mathrm{Ca}^{2+}$-activated outward current, although there are some components that are resistant to TEA in both the InsP ${ }_{3}$-induced and $\mathrm{Ca}^{2+}$-activated outward currents. A TEA-resistant, $\mathrm{Ca}^{2+}$-dependent $\mathrm{K}^{+}$conductance has been observed previously in response to a depolarizing pulse in voltage-clamped ncurons in a variety of preparations, e.g., bullfrog sympathetic ganglion neurons (Pennefather et al., 1985), neuroblastoma cells (Moolenaar and Spector, 1979), and molluscan neurons (Aldrich et al., 1979; Smith and Zuckler, 1980; Barish and Thompson, 1983; Deitmer and Eckert, 1985; Kehoe, 1985). In certain molluscan neurons, intracellularly injected $\mathrm{Ca}^{2+}$ ions induce a long-duration, $\mathrm{K}^{+}$-dependent response (Meech, 1974; Hofmeier and Lux, 1981), but the sensitivity of the conductance to TEA and the possible mediation of intracellular $\mathrm{InsP}_{3}$ were not evaluated.

As was shown in Figures 13 and 14, the calmodulin inhibitor W-7 almost completely inhibits both the Ins $\mathrm{P}_{3}$-induced outward current and the $\mathrm{Ca}^{2+}$-activated outward current. These effects do not appear to be secondary to interference with changes of the resting membrane conductance by bath-applied W-7 because the resting holding current and membrane conductance of identified neurons were not affected in the presence of W-7. The inhibitory effects of $\mathrm{W}-7$ on these currents were only partially reversible, even after prolonged washings (Fig. 14). In another system, Xenopus oocytes, Dascal and his collaborators (1985) have shown that extracellular application of TFP, the widely used calmodulin inhibitor (Weiss et al., 1982), inhibited both the $\mathrm{Cl}^{-}$current evoked by $\mathrm{ACh}$ and the $\mathrm{Cl}^{-}$current induced by intracellular injection of $\mathrm{Ca}^{2+}$. The inhibitory cffect of TFP on these currents was also only partially reversible, even after prolonged washings.

Calmodulin inhibitors, such as TFP and W-7, have been shown to inhibit calcium/calmodulin-dependent enzymes as well as the calcium-phospholipid-dependent protein kinase in vitro in the bag cell neurons of Aplysia (DeRiemer et al., 1984). The mechanism by which InsP $P_{3}$ causes the opening of $\mathrm{K}^{*}$ channels is not known. Since $\mathrm{W}-7$ can inhibit the $\mathrm{InsP}_{3}$-induced outward current as weil as the $\mathrm{Ca}^{2+}$-activated outward current, both currents, recorded from identified neurons of Aplysia, may involve a common mechanism mediated by the calcium/calmodulindependent enzyme or the calcium-phospholipid-dependent protein kinase for the final opening of a specific $\mathrm{K}^{+}$channel. In other systems, it has been reported that the $\mathrm{Ca}^{2+}-$ calmodulin complex can regulate phosphorylation of cellular proteins and 

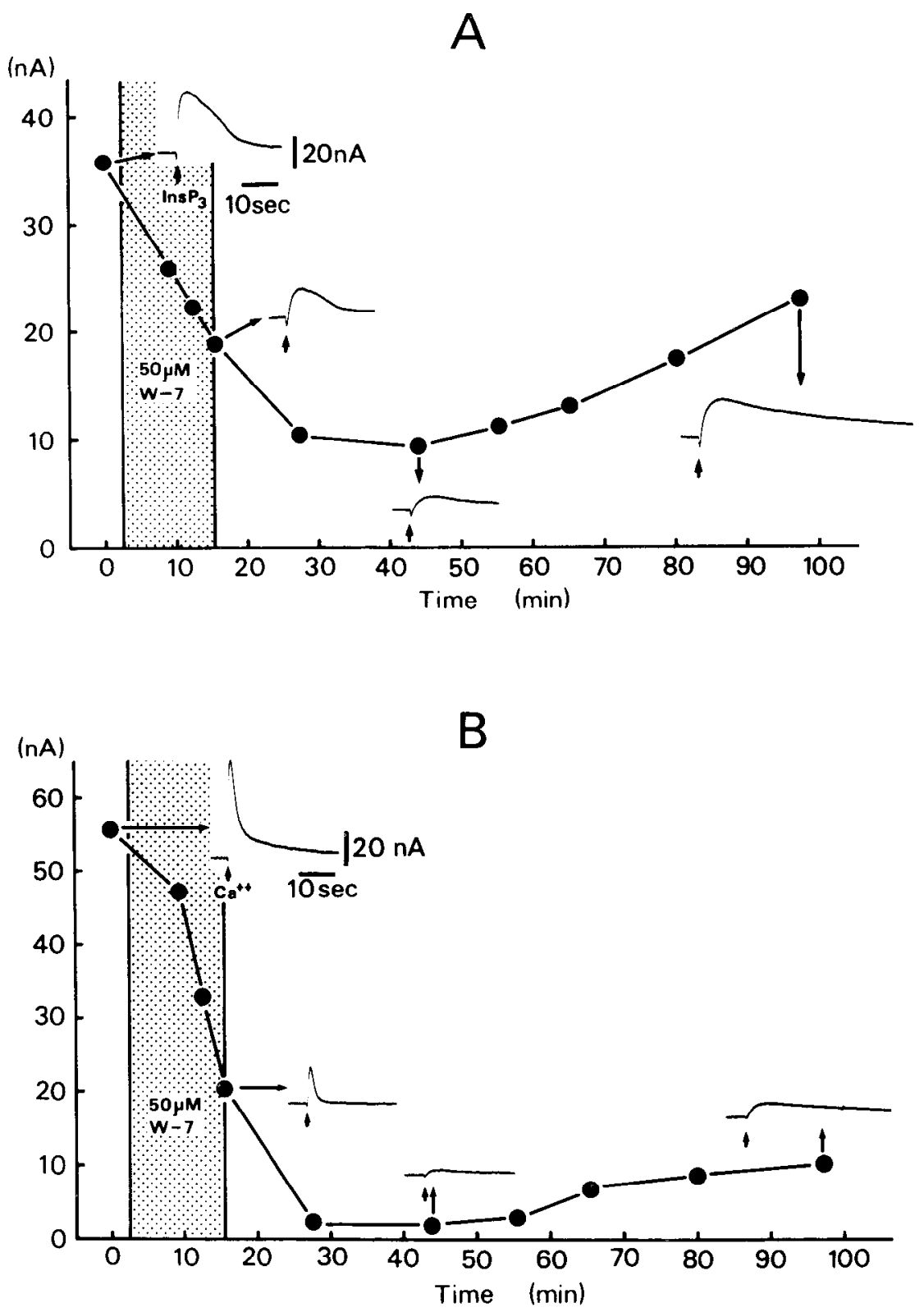

Figure 14. Time course of the inhibitory effects of $50 \mu \mathrm{M} \mathrm{W}-7$ on the InsP $\mathrm{P}_{3}$ induced outward current $(A)$ and the $\mathrm{Ca}^{2+}$-activated outward current $(B)$ recorded from the same neuron R12. Holding potential was $-40 \mathrm{mV}$. W-7 was bath-applied for 13 min (stippled areas). Ins $\mathrm{P}_{3}$ was injected by a single constant pressure pulse ( $60 \mathrm{msec}, 2 \mathrm{~kg} /$ $\mathrm{cm}^{2}$ in $A$ ) and $\mathrm{CaCl}_{2}$ by a single pressure pulse $\left(30 \mathrm{msec}, 2 \mathrm{~kg} / \mathrm{cm}^{2}\right.$ in $B$ ). Note that the inhibitory effects of W-7 on these currents were, again, only partially reversible, even after prolonged ( $>1 \mathrm{hr}$ ) washings. activate the $\mathrm{Ca}^{2+}$-dependent cyclic nucleotide phosphodiesterase (Means and Dedman, 1980; Cheung, 1981; Stoclet, 1981). On the other hand, De Peyer and his collaborators (1982) have shown that addition of the catalytic subunit of cAMP-dependent protein kinase to internally perfused Helix neurons increases a $\mathrm{Ca}^{2+}$-dependent net outward current, and have proposed that cAMP-dependent protein phosphylation regulates the $\mathrm{Ca}^{2+}$-activated $\mathrm{K}^{+}$conductance in these neurons. It seems likely that changes in Ins $\mathrm{P}_{3}$ levels may coordinate a variety of biochemical changes induced by other second messengers, such as cAMP and diacylglycerol. Further studies are required to examine whether the time course and amount of intracellular $\operatorname{InsP}_{3}$ production induced by the neurotransmitter are correlated with an increase in intracellular free $\mathrm{Ca}^{2+}$ concentration in neurons using intracellular $\mathrm{Ca}^{2+}$ as an intermediate second-messenger transducer.

\section{References}

Agranoff, B. W., P. Murthy, and E. B. Seguin (1983) Thrombin-induced phosphodiesteratic cleavage of phosphatidylinositol bisphos- phate in human platelets. J. Biol. Chem. 258: 2076-2078.

Aldrich, Jr., R. W., P. A. Getting, and S. H. Thompson (1979) Inactivation of delayed outward current in molluscan neurone somata. J. Physiol. (Lond.) 291: 507-530.

Barish, M. E., and S. H. Thompson (1983) Calcium buffering and slow recovery kinetics of calcium-dependent outward current in molluscan neurones. J. Physiol. (Lond.) 337: 201-219.

Berridge, M. J. (1983) Rapid accumulation of inositol trisphosphate reveals that agonists hydrolyse polyphosphoinositides instead of phosphatidylinositol. Biochem. J. 212: 849-858.

Berridge, M. J. (1984) Inositol trisphosphate and diacylglycerol as second messengers. Biochem. J. 220: 345-360.

Berridge, M. J., and R. F. Irvine (1984) Inositol trisphosphate, a novel second messenger in cellular signal transduction. Nature $312: 315-$ 321.

Bond, M., T. Kitazawa, A. P. Somlyo, and A. V. Somlyo (1984) Release and recycling of calcium by the sarcoplasmic reticulum in guineapig portal vein smooth muscle. J. Physiol. (Lond.) 355: 677-695.

Brown, J. E., L. J. Rubin, A. J. Ghalayini, A. P. Tarver, R. F. Irvine, M. J. Berridge, and R. E. Anderson (1984) Myo-inositol polyphosphate may be a messenger for visual excitation in Limulus photoreceptors. Nature 311: 160-163.

Burgess, G. M., P. P. Godfrey, J. S. McKinney, M. J. Berridge, R. F. Irvine, and J. W. Putney, Jr. (1984) The second messenger linking 
receptor activation to internal Ca release in liver. Nature 309: 6366.

Castellucci, V. F., E. R. Kandel, J. H. Schwartz, F. D. Wilson, A. C. Nairn, and P. Greengard (1980) Intracellular injection of the catalytic subunit of cyclic AMP-dependent protein kinase simulates facilitation of transmitter release underlying behavioral sensitization in Aplysia. Proc. Natl. Acad. Sci. USA 77: 7492-7496.

Cheung, W. Y. (1981) Calmodulin and the adenylate cyclase-phosphodiesterase system. Cell Calc. 2: 263-280.

Dascal, N., B. Gillo, and Y. Lass (1985) Role of calcium mobilization in mediation of acetylcholine-evoked chloride currents in Xenopus laevis oocytes. J. Physiol. (Lond.) 366: 299-313.

Deitmer, J. W., and R. Eckert (1985) Two components of Ca-dependent potassium current in identified neurones of Aplysia californica. Pfluegers Arch. 403: 353-359.

De Peyer, J. E., A. B. Cachelin, I. B. Levitan, and H. Reuter (1982) $\mathrm{Ca}^{2+}$-activated $\mathrm{K}^{+}$conductance in internally perfused snail neurons is enhanced by protein phosphorylation. Proc. Natl. Acad. Sci. USA 79: 4207-4211.

DeRiemer, S. A., L. K. Kaczmarek, K. Albert, and P. Greengard (1983) Calcium/phospholipid-dependent protein phosphorylation in Aplysia neurons. Soc. Neurosci. Abstr. 9: 77.

DeRiemer, S. A., L. K. Kaczmarek, Y. Lai, T. L. McGuinness, and P. Greengard (1984) Calcium/calmodulin-dependent protein phosphorylation in the nervous system of Aplysia. J. Neurosci. 4: 16181625 .

Deterre, P., D. Paupardin-Tritsch, J. Bockaert, and H. M. Gerschenfeld (1982) cAMP-mediated decrease in $\mathrm{K}^{+}$conductance evoked by serotonin and dopamine in the same neuron: A biochemical and physiological single-cell study. Proc. Natl. Acad. Sci. USA 79: 7934-7938.

Downes, C. P., M. C. Mussat, and R. H. Michell (1982) The inositol trisphosphate phosphomonoesterase of the human erythrocyte membrane. Biochem. J. 203: 169-177.

Drummond, A. H., J. A. Benson, and I. B. Levitan (1980) Serotonininduced hyperpolarization of an identified Aplysia neuron is mediated by cyclic AMP. Proc. Natl. Acad. Sci. USA 77: 5013-5017.

Fein, A., R. Payne, D. W. Corson, M. J. Berridge, and R. F. Irvine (1984) Photoreceptor excitation and adaptation by inositol 1,4,5trisphosphate. Nature 311: 157-160.

Fink, L., J. A. Connor, J. A. Strong, and L. K. Kaczmarek (1985) Inositol trisphosphate injections and imaging of the calcium indicator fura-2 in molluscan neurons. Neurosci. Abstr. 11: 854.

Frazier, W. T., E. R. Kandel, I. Kupfermann, R. F. Waziri, and R. Coggeshall (1967) Morphological and functional properties of identified neurons in the abdominal ganglion of Aplysia californica. $\mathbf{J}$. Neurophysiol. 30: 1288-1351.

Gorman, A. L. F., and A. Hermann (1979) Internal effects of divalent cations on potassium permeability in molluscan neurones. J. Physiol.(Lond.) 296: 393-410.

Greengard, P. (1978) Phosphorylated proteins as physiological effectors. Science 199: 146-152.

Hara, N., M. Sawada, and I. Maeno (1985) Influences of pressureinjected cyclic AMP on the membrane current and characteristics of an identified neuron of Aplysia kurodai. Jpn. J. Physiol. 35: 9851012.

Hashimoto, T., M. Hirata, T. Itoh, Y. Kanmura, and H. Kuriyama (1986) Inositol 1,4,5-trisphosphate activates pharmacochemical coupling in smooth muscle of the rabbit mesenteric artery. J. Physiol. (Lond.) 370: 605-618.

Hermann, A., and A. L. F. Gorman (1979) Blockade of voltage-dependent and $\mathrm{Ca}^{2+}$-dependent $\mathrm{K}^{+}$current components by internal $\mathrm{Ba}^{2+}$ in molluscan pacemaker neurons. Experientia 35: 229-231.

Hermann, A., and K. Hartung (1982) Properties of a Ca ${ }^{2+}$ activated $\mathrm{K}^{+}$conductance in Helix neurones investigated by intracellular $\mathrm{Ca}^{2+}$ ionophoresis. Pfluegers Arch. 393: 248-253.

Hidaka, H., Y. Sakai, T. Tanaka, T. Endo, S. Ohno, Y. Fujii, and T. Nagata (1981) $N$-(6-aminohexyl)-5-chloro-1-naphthalene-sulfonamide, a calmodulin antagonist, inhibits cell proliferation. Proc. Natl. Acad. Sci. USA 78: 4354-4357.

Hirata, M., E. Suematsu, T. Hashimoto, T. Hamachi, and T. Koga (1984) Release of $\mathrm{Ca}^{2+}$ from a non-mitochondrial store site in peritoneal macrophages treated with saponin by inositol 1,4,5-trisphosphate. Biochem. J. 223: 229-236.

Hofmeier, G., and H. D. Lux (1981) The time courses of intracellular free calcium and related electrical effects after injection of $\mathrm{CaCl}_{2}$ into neurones of the snail, Helix pomatia. Pfluegers Arch. 391: 242-251.
Joseph, S. K., A. P. Thomas, R. J. Williams, R. F. Irvine, and J. R. Williamson (1984) Myo-inositol 1,4,5-trisphosphate: A second messenger for the hormonal mobilization of intracellular $\mathrm{Ca}^{2+}$ in liver. J. Biol. Chem. 259: 3077-3081.

Kaczmarek, L. K., and F. Strumwasser (1984) A voltage-clamp analysis of currents underlying cyclic AMP-induced membrane modulation in isolated peptidergic neurons of Aplysia. J. Neurophysiol. 52: 340-349.

Kakiuchi, S., R. Yamazaki, and H. Nakajima (1970) Properties of heat-stable phosphodiesterase activating factor isolated from brain extract. Studies on cyclic $3^{\prime}, 5^{\prime}$-nucleotide phosphodiesterase. Proc. Jpn. Acad. 46: 587-592.

Kehoe, J. S. (1985) Synaptic block of a calcium-activated potassium conductance in Aplysia neurones. J. Physiol. (Lond.) 369: 439-474.

Kehoe, I. S., and A. Marty (1980) Certain slow synaptic responses: Their properties and possible underlying mechanisms. Annu. Rev. Biophys. Bioeng. 9: 437-465.

Koester, J., and E. R. Kandel (1977) Further identification of neurons in the abdominal ganglion of Aplysia using behavioral criteria. Brain Res. 121: 1-20.

Kowarski, D., H. Shuman, A. P. Somlyo, and A. V. Somlyo (1985) Calcium release by noradrenaline from central sarcoplasmic reticulum in rabbit main pulmonary artery smooth muscle. J. Physiol. (Lond.) 366: 153-175.

Kunze, D. L., and A. M. Brown (1971) Internal potassium and chloride activities and the effects of acetylcholine on identified Aplysia neurones. Nature 229: 229-231.

McCaman, R. E., D. G. McKenna, and J. K. Ono (1977) A pressure system for intracellular ejections of picoliter volumes. Brain Res. 136: 141-147.

Means, A. R., and J. R. Dedman (1980) Calmodulin: An intracellular calcium receptor. Nature 285: 73-77.

Meech, R. W. (1974) The sensitivity of Helix aspersa neurones to injected calcium ions. J. Physiol. (Lond.) 237: 259-277.

Meech, R. W. (1978) Calcium-dependent potassium activation in nervous tissues. Annu. Rev. Biophys. Bioeng. 7: 1-18.

Meech, R. W., and N. B. Standen (1975) Potassium activation in Helix aspersa neurones under voltage clamp: A component mediated by calcium influx. J. Physiol. (Lond.) 249: 211-239.

Michell, R. H. (1975) Inositol phospholipids and cell surface receptor function. Biochim. Biophys. Acta 415: 81-147.

Moolenaar, W. H., and I. Spector (1979) The calcium current and the activation of a slow potassium conductance in voltage-clamped mouse neuroblastoma cells. J. Physiol. (Lond.) 292: 307-323.

Nishizuka, Y. (1984) The role of protein kinase C in cell surface signal transduction and tumour promotion. Nature 308: 693-698.

Oron, Y., N. Dascal, E. Nadler, and M. Lupu (1985) Inositol 1,4,5trisphosphate mimics muscarinic response in Xenopus oocyte. Nature 311: 141-143.

Pennefather, P., B. Lancaster, P. R. Adams, and R. A. Nicoll (1985) Two distinct $\mathrm{Ca}$-dependent $\mathrm{K}$ currents in bullfrog sympathetic ganglion cells. Proc. Natl. Acad. Sci. USA 82: 3040-3044.

Poggioli, J., S. J. Weiss, J. S. McKinney, and J. W. Putney, Jr. (1983) Effects of antimycin A on receptor-activated calcium mobilization and phosphoinositide metabolism in rat parotid gland. Mol. Pharmacol. 23: 71-77.

Putney, Jr., J. W., G. M. Burgess, S. P. Halenda, J. S. McKinney, and R. P. Rubin (1983) Effects of secretagogues of [ $\left.{ }^{32} \mathrm{P}\right]$-phosphatidylinositol-4,5-bisphosphate metabolism in the exocrine pancreas. Biochem. J. 212: 483-488.

Sato, M, G. Austin, H. Yai, and J. Maruhashi (1968) The ionic permeability changes during acetylcholine-induced responses of Aplysia ganglion cell. J. Gen. Physiol. 51: 321-345.

Sawada, M., K. Enomoto, and T. Maeno (1980) Ionic mechanism of inhibition of long duration in Aplysia synapse. J. Neurosci. Res. 5: $537-553$.

Seamon, K. B., and J. W. Daly (1982) Guanosine $5^{\prime}$-( $\beta, \gamma$-imido)triphosphate inhibition of forskolin-activated adenylate cyclase is mediated by the putative inhibitory guanine nucleotide regulatory protein. J. Biol. Chem. 257: 11591-11596.

Siegelbaum, S. A., J. S. Camardo, and E. R. Kandel (1982) Serotonin and cyclic AMP close single $\mathrm{K}^{+}$channels in Aplysia sensory neurones. Nature 299: 413-417.

Smith, S. J., and R. S. Zucker (1980) Aequorin response facilitation and intracellular calcium accumulation in molluscan neurones. $J$. Physiol. (Lond.) 300: 167-196. 
Somlyo, A. V., M. Bond, A. P. Somlyo, and A. Scarpa (1985) Inositol trisphosphate-induced calcium release and contraction in vascular smooth muscle. Proc. Natl. Acad. Sci. USA 82: 5231-5235.

Stoclet, J. C. (1981) Calmodulin: An ubiquitous protein which regulates calcium-dependent cellular functions and calcium movements. Biochem. Pharmacol. 30: 1723-1729.

Streb, H., R. F. Irvine, M. J. Berridge, and I. Schulz (1983) Release of $\mathrm{Ca}^{2+}$ from a nonmitochondrial intracellular store in pancreatic acinar cells by inositol-1,4,5-trisphosphate. Nature 306: 67-69.

Strong, J. A. (1984) Modulation of potassium current kinetics in bag cell neurons of Aplysia by an activator of adenylate cyclase. J. Neurosci. 4: 2772-2783.
Suematsu, E., M. Hirata, T. Hashimoto, and H. Kuriyama (1984) Inositol 1,4,5-trisphosphate release $\mathrm{Ca}^{2+}$ from intracellular store sites in skinned single cells of porcine coronary artery. Biochem. Biophys. Res. Commun. 120: 481-485.

Thompson, S. (1982) Aminopyridine block of transient potassium current. J. Gen. Physiol. 80: 1-18.

Waloga, G., and R. E. Anderson (1985) Effects of inositol-1,4,5-trisphosphate injections into salamander rods. Biochem. Biophys. Res. Commun. 126: 59-62.

Weiss, B., W. C. Prozialeck, and T. L. Wallace (1982) Interaction of drugs with calmodulin: Biochemical, pharmacological and clinical implications. Biochem. Pharmacol. 31: 2217-2226. 